\title{
THE TREASURY'S PROPOSALS FOR TAX REFORM: A CANADIAN PERSPECTIVE
}

\author{
GoRdon BALE*
}

\section{INTRODUCTION}

The U.S. Treasury Department's proposal entitled "Tax Reform for Fairness, Simplicity, and Economic Growth" 1 is bold and exciting and will generate much heated debate. It calls for a greatly broadened income base, for full inclusion of all real capital gains, for comprehensive measures to adjust for inflation, for depreciation allowances to approximate economic depreciation, for the elimination of special tax preferences for specific industries, for partial relief from the double taxation of dividends, for the curtailment of tax shelters, for tax simplification and for substantially reduced personal and corporate tax rates. These proposals are in response to President Reagan's call for basic tax reform. In his State of the Union address, the President said:

There is a better way: Let us go forward with an historic reform for fairness, simplicity and incentives for growth. I am asking Secretary Don Regan for a plan for action to simplify the entire tax code so all taxpayers, big and small, are treated more fairly. ${ }^{2}$

In pursuing this mandate for comprehensive reform, the Treasury Department focused on four options: A pure flat rate income tax, a modified flat rate income tax, a tax on income that is consumed, and a general sales tax levied either on value-added or retail sales. The objectives of the Treasury Department included: "[L]ower marginal tax rates; reduced interference with private economic decisions; simplicity; revenues equal to those of the existing tax system; fairness for families; equal treatment of all sources and uses of income; an unchanged distribution of tax burdens across income classes; and encouragement to economic growth."3 The Treasury concluded that a "modified flat tax" levied on a much more comprehensive income base would best reconcile such objectives." The modified flat tax would replace the present fourteen tax brackets ranging from $11 \%$ to $50 \%$ with three brackets of $15 \%, 25 \%$, and $35 \%$. The Treasury believes that these large rate

\footnotetext{
Copyright $\odot 1985$ by Law and Contemporary Problems

* Professor of Law, Queen's University, Kingston, Canada. An earlier version of this article was published in 39 CAN. TAX J. 269 (1985).

1. U.S. Dep't of the Treas., Report to the President: Tax Reform for Fairness, Simplicity, AND Economic Growth (1984) (in three volumes, Vol. 1, Overview; Vol. 2, General Explanation of the Treasury Proposals; and Vol. 3, Value-Added Tax) [hereinafter cited as Treas. REPORT].

2. State of the Union Address, Jan. 25, 1984, quoted in 1 TREAS. RePORT, supra note 1, at iii.

3. 1 TREAs. Report, supra note 1 , at iv.

4. Id. at 23.
} 
reductions will "open wide the doors of opportunity to those who are willing to work, to save and invest, and to innovate." With the consequent neutrality, investment decisions will be determined by economic rather than tax considerations. This, the Treasury believes, will result in better allocation of capital among industries and in accelerated growth. The Treasury warns that unless broad reform is made and most special tax benefits are eliminated, taxpayer morale will continue to deteriorate and it will be more and more difficult to deny appeals by others for preferential treatment. ${ }^{6}$

It is surprising that a document suggesting so radical a change in the tax system would originate from the Reagan Administration. But the proposals are not radical from the perspective of income redistribution because there is to be, in general, no change in the distribution of individual tax burdens across income classes. The proposed broad-based and more neutral tax system will not be without appeal to neoconservatives: The tax plan can be interpreted as a denial of the government's role in formulating an industrial policy, even a very generalized one, implemented through the tax system. The diminishing band of "supply-siders" will be irate about the proposed abolition of the investment tax credit and of the Accelerated Cost Recovery System (ACRS) for the depreciation of capital assets. Persons who are less ideologically inclined, in my opinion, will conclude that the Treasury proposals are imbued with the spirit of true tax reform. The proposals go far towards achieving horizontal equity.

Treasury Secretary Regan fully appreciated that the journey towards fundamental tax reform will be difficult; he stated:

These proposals are bold, and they will be controversial. Those who benefit from the current tax preferences that distort the use of our nation's resources, that complicate paying taxes for all of us, and that create inequities and undermine taxpayer morale will complain loudly and seek support from every quarter. But a far greater number of Americans will benefit from the suggested rate reduction and simplification. The achievement of fundamental tax reform-and the manifest benefits it would entailwill require extraordinary leadership. ${ }^{7}$

\section{II}

\section{Comparisons with the Carter Commission Report}

The Treasury Department proposals are in some ways almost as comprehensive as those of Canada's Carter Commission ${ }^{8}$ of almost two decades ago. The Carter Commission was so intellectually faithful to the Haig-Simons definition of income ${ }^{9}$ that it proposed the inclusion of gifts and

5. Id.

6. Id. at 25.

7. Id. at iv-v.

8. Report of the Royal Comm'n on TAXation (1966) (published in six volumes) (referred to as the Carter Commission after its Chairman, Kenneth LeM. Carter) [hereinafter cited as CarTER REPORT].

9. H. Simons, Personal Income Taxation 50 (1938); Haig, The Concept of Income-Economic and Legal Aspects, reprinted in ReAdings IN the Economics of TAXATION 54, 75 (R. Musgrave \& C. Shoup eds. 1959). 
inheritances in the income tax base of the recipient. Similarly, the Treasury proposals will greatly expand the income tax base, but its proposals are tempered to a greater extent by political realities. For example, gifts and inheritances are not to be included in the income tax base due to recognition of the squatter's, or vested, rights of estate and gift taxation. The Treasury proposals would limit the deductibility of interest but would not eliminate the current deduction for mortgage interest, although this deduction would be restricted to mortgage interest on one principal residence. The Department of the Treasury was tailoring its proposal to political realities. Having suggested that state and local taxes should no longer be deductible, the Treasury probably thought that it could not also curtail mortgage interest on a principal residence nor repeal the tax exemption for general purpose state and local government bonds.

The Treasury acknowledges that the interest exemption for state and local government bonds cannot be reconciled with a comprehensive income tax, that the subsidy it provides is inefficient with too much benefit accruing to high income bondholders and too little cost savings to state and local governments, and that the exemption is based on an outmoded understanding of federalism. Nevertheless, the Treasury proposes only to limit abuses because "this exemption appears to be an accepted part of the fiscal landscape." 10 This reluctance to deal with such a patent defect in the income tax base stems in part from the political reality that the federal government cannot gore state and local governments by both making their taxes nondeductible and eliminating the tax subsidy of the interest exemption. In part, it flows from undertaking tax reform when there is a $\$ 200$ billion plus deficit and the mood of the President and the country is against tax increases. These circumstances make it inappropriate to suggest direct expenditure programs to replace existing ill-advised tax expenditures. Basic tax reform is always exceedingly difficult; the budget deficit and the need to cut expenditures compound the problem at this time.

Another similarity between the Carter Report and the Treasury proposal is that each was presented as an integrated package. The Treasury stresses that neutrality among industries can be achieved only by eliminating the special preferences benefiting each industry. ${ }^{11}$ Like the Carter Report, the Treasury proposals would replace percentage depletion and the expensing of intangible drilling costs for the extractive industries with cost depletion to achieve identical general rules for income measurement for all multiperiod production. The Treasury also insists that many changes are mutually dependent and must occur simultaneously if inequities, distortions or complexities are to be avoided. ${ }^{12}$ The preeminent example of this is the comprehensive proposal for indexation or inflation-proofing of the tax system. For example, the Treasury rightly emphasizes that "[a]llowing

10. 1 TREAs. RePORT, supra note 1 , at 135.

11. Id. at iv, 125 .

12. Id. at iv. 
inflation adjustment for capital gains, depreciation, and inventories, without also adjusting interest income and expense, would be neither fair nor neutral."13 Inflation-proofing the income tax must be done comprehensively. The Treasury cautions that changes in the package would require rate structure changes in order to keep tax burdens constant across income classes and in total. ${ }^{14}$ Each deduction, deferral or credit that is retained contrary to the proposal recommendations will inevitably mean that higher rates will be necessary to achieve a given revenue target.

The Carter Report and the Treasury proposal differ with respect to progressivity of the income tax. The Carter Commission had no doubts or qualms about recommending a progressive tax structure. It expressed the view that most government expenditures should be financed by taxes levied in accordance with ability to pay, which means that "the government must seek to impose progressive marginal rates on all additions to personal economic power, without regard to the source of those increments in power." 15 The Carter Commission also believed that reducing the progressiveness of the personal income tax would only modestly increase savings with a substantial loss in vertical equity. ${ }^{16}$

Within the last decade in western societies, there has been a significant ideological shift towards neoconservatism which has probably proceeded further in the United States than in Canada. ${ }^{17}$ A manifestation of this shift is the Treasury's rhetorical downplaying of progressivity, even though the proposal's impact is to replicate exactly the present burden of distribution. The plan, with its three tax brackets of $15 \%, 25 \%$, and $35 \%$ applied to a much broader tax base, is not described as a fairer and more effective progressive tax system but as "a modified flat tax." 18 It should not, however, be inferred that the Treasury is unconcerned about vertical or distributional equity. The Treasury rejected a pure flat rate tax-even one with generous personal exemptions and zero-bracket amounts designed to levy no tax on persons at or below the poverty level-because that would involve a substantial shift of the tax burden from those in the highest income brackets to low and middle income taxpayers. ${ }^{19}$ The prospect of massive redistribution of tax burdens implicit in a revenue-neutral pure flat tax caused the Treasury to reject it. The Treasury's commitment to a progressive tax system is also shown by its proposal to tax the unearned income of children under fourteen years of age, which is attributable to property transferred from their parents, at the parents' marginal tax rates. The Treasury says that "[i]ncome splitting undermines the progressive rate structure and is a source of unfairness in the

13. Id. at 99 .

14. Id.

15. 2 CARTER REPORT, supra note 8 , at 10 .

16. Id. at 178.

17. Nevitte \& Gibbins, Neoconservatism: Canadian Variations on an Ideological Theme?, 10 Canadian Pub. Pol'y 384 (1984).

18. 1 Treas. RePORT, supra note 1 , at 23.

19. Id. at 21-23. 
tax system,"20 and that its proposal "would help to ensure the integrity of the progressive tax rate structure, which is designed to impose tax burdens in accordance with each taxpayer's ability to pay." 21 The current dominance of neoconservative ideology has resulted in a deemphasis of the virtue of a progressive tax structure, but the belief in its essential fairness remains largely unimpaired.

One other way in which the two tax plans differ is in their approach to personal exemptions. Surprisingly, the Treasury takes a more liberal view of the function of personal exemptions in an income tax system than did the Carter Report. The Treasury proposal states that "[f]amilies with incomes at or below the poverty level should not be subject to income tax."22 In contrast, the Carter Report stated:

The idea that income taxes should not reduce income below "subsistence" is laudable in its intention but, we believe, misconceived. Subsistence has no absolute meaning. It is the relative positions of individuals and families that are important. Furthermore, neither exemptions from tax nor credits against tax can ensure that every Canadian has a minimum income. This objective can only be achieved through increased government transfer payments including, for example, refundable credits against taxes. The income tax system as such cannot be used to help people without incomethose who most need the help. ${ }^{23}$

I have previously described this as callous nonsense. ${ }^{24}$ Granted that subsistence can have no absolute meaning and a positive tax system can do nothing for those below the exemption level, an income tax nevertheless need and should not exacerbate the problems of those in poverty through unreasonably low personal exemptions.

The Carter Commission conveyed the impression that it was a good lesson in citizenship for persons with less than subsistence income to pay some income tax. As the Commission recognized that such persons would also pay sales taxes and would bear part of the burden of municipal property taxes and the corporate income tax, its approach to personal exemptions was perplexing. The Commission was intent on achieving a tax system in which middle and upper middle income Canadian taxpayers did not bear a significantly higher burden than their counterparts in the United States. ${ }^{25}$ In consequence, it proposed personal exemptions which were unduly low so that tax rates could be held down. The Carter Report was certainly concerned about the "brain drain"; 26 but while this is a legitimate concern it must also be recognized that taxes represent the price paid for government services. As the kind and level of services offered by the governments of Canada and the

20. 2 Treas. RePort, supra note 1 , at 92 .

21. Id. at 94 .

22. I TREAS. RePORT, supra note 1 , at 66 .

23. 3 CARTER REPORT, supra note 8, at 21.

24. Bale, The Individual and Tax Reform in Canada, 49 CAnadian B. Rev. 24, 59 (1971).

25. 3 CARTER REPORT, supra note 8 , at 158 . "We are, however, concerned with reducing Canadian taxes on skilled workers and professionals to the point where there are no major tax incentives for emigration to the United States." Id.

26. Id. The "brain drain" refers to the phenomenon of highly skilled and professional workers leaving Canada for jobs in the United States or other foreign countries. 
United States differ, there is no reason to expect the price to be the same. Equalization grants, which are paid to the provinces to ensure that all Canadians can enjoy comparable levels of public service while paying only comparable levels of taxation, have no counterpart in the United States. Furthermore, the Canadian national health system also justifies substantially higher taxes in Canada than in the United States, where health care is largely privately financed.

Although changes in personal exemptions have in the past been determined largely by revenue consideration, it is now recognized both in Canada and in the United States that an income tax should not worsen the condition of those with less than subsistence income. Personal exemptions or zero-bracket amounts must therefore be set at levels which will shield persons with only subsistence income from an income tax. This was clearly acknowledged by the Treasury Report.

\section{III}

\section{The Treasury Report}

Considering all the tax reform measures contained in the Treasury Report in one article is impossible. However, its flavor can be conveyed by brief mention of some of the proposals. For instance, all employee fringe benefits are to be taxed, with the exceptions of contributions to qualified retirement plans and of health care premiums up to a designated limit. ${ }^{27}$ Thus, the present exclusion for employer-provided group term life insurance and death benefits is to be repealed, as well as the special treatment of incentive stock options. ${ }^{28}$ Even the exclusion for rental allowance or rental value of a minister's home is to be abolished. ${ }^{29}$ All unemployment compensation is to be made taxable, and the tax exemption for workers' compensation is to be repealed. ${ }^{30}$ This stringent tax treatment of ordinary employees is also to be meted out to executives and the self-employed. To reduce abuses arising from the deduction of personal living costs as business expenses, no deduction will be allowed for most entertainment expenses and the business travel deduction for meals and lodging will be limited. ${ }^{31}$ Tax treatment of the elderly, blind, and disabled will be rationalized by providing them with a single tax credit, including the additional personal exemptions, instead of the special treatment they currently receive which gives more benefit to high income taxpayers than to those who need assistance. ${ }^{32}$ There are also many proposals which limit tax shelter opportunities and will promote neutrality in the taxation of business income.

27. 1 TREAS. REPORT, supra note 1 , at $73-74$ (proposed premium limit set at $\$ 70$ per month for a single person and $\$ 175$ per month for a family).

28. 2 Treas. Report, supra note 1 , at 41-42.

29. Id. at 49-50.

30. Id. at $\mathbf{5 1 - 5 5}$.

31. Id. at $81-85,86-90$.

32. Id. at 9-11. 
The Treasury Report contains a comprehensive and balanced set of proposals for fundamental tax reform. Four aspects of the Report will be considered under the following headings: a) abolition of the deduction for state and local taxes; b) termination of the alternative minimum tax; c) inflation-proofing of the tax system; and d) the dividend-paid deduction for corporations.

\section{A. Abolition of the Deduction for State and Local Taxes}

The proposal to phase out over a two-year period the itemized deduction for state and local income taxes and other taxes that are not incurred in carrying on a trade or business ${ }^{33}$ strikes a Canadian as eminently sensible. This reaction arises, in part, because provincial and local taxes are not deductible in Canada, and one tends to feel comfortable with a familiar approach. It is, however, more than that. The rationale for the deductibility of state and local taxes is simply very weak. Unless the taxes are incurred in an income-producing activity, there is no compelling reason for a deduction; indeed, if one were to design a new tax system for a federal country on a clean slate, one would provide very limited deductibility. However, deductibility of state and local taxes has a long history in the United States. The 1865 Act provided that "all national, state, county, and municipal taxes paid within the year" 34 were deductible from the income of the payor. The ill-fated 1894 Act, promptly ruled unconstitutional, ${ }^{35}$ also made national, state, county, school, and municipal taxes deductible. ${ }^{36}$ After adoption of the sixteenth amendment to the Constitution, permitting the federal government to levy income taxes, Congress, in the Act of 1913, enacted basically the same personal deductions as in the 1894 Act including the deduction for taxes. ${ }^{37}$ In fact, until specifically prohibited in $1919,^{38}$ federal income tax paid in the current year but levied on the previous year's income was deductible from the current year's income. ${ }^{39}$ In 1943, federal excise taxes were removed from the list of deductible taxes. ${ }^{40}$ In 1964, the deduction was ended for state and local taxes on tobacco and alcoholic beverages, automobile and driver's licenses, and other state and local selective excises, except gasoline taxes. ${ }^{41}$ In 1979, state and local taxes on the sale of gasoline, diesel fuel, and other motor fuels

33. I Treas. RePORT, supra note 1 , at 78-83, and 2 Treas. RePORT, supra note 1 , at 62-65. The President's Proposals would be effective as of January 1, 1986, rather than phasing in the deduction's elimination over two years. The President's Tax Proposals to the Congress for Fairness, Growth, and Simplicity 65 (1985) [hereinafter cited as the Pres. Proposals].

34. Act of March 3, 1865, ch. 78, $\$ 1,13$ Stat. 469, 479 (amending the Revenue Act of 1864 , ch. 172, \& 117, 13 Stat. 218, 281).

35. Pollock v. Farmers' Loan \& Trust Co., 158 U.S. 601 (1894).

36. Revenue Act of 1894 , ch. $349, \& 28,28$ Stat. 509, 553.

37. Revenue Act of 1913, ch. 16, $\$$ B, 38 Stat. $114,167$.

38. Revenue Act of 1918, ch. 18, \& $214(\mathrm{a})(3)(\mathrm{a}), 40$ Stat. 1057, 1067 (1919).

39. The 1918 Code made all taxes deductible. Since then there has been a general narrowing, leaving only specified taxes deductible.

40. Revenue Act of 1943, ch. 63, \& 111, 58 Stat. 21, 34 (1944).

41. Revenue Act of 1964, Pub. L. No. 88-272, \& 207, 78 Stat. 19, 40. 
were eliminated from the list of taxes for which there is an itemized deduction. ${ }^{42}$

Although the deductibility of state and local taxes has a long history, it appears that it was "casually granted at the outset" 43 and should certainly be reexamined today. The Treasury notes that the deduction for state and local taxes results in one of the most serious omissions from the income tax base. Repeal of the deduction is projected to generate $\$ 33.9$ billion in revenue for $1988^{44}$ and to recoup approximately $32 \%$ of the revenue loss which the proposed rate reduction will cause. ${ }^{45}$ To justify keeping the deduction, one would have to establish either that the deduction is required for the accurate measurement of income or that it represents an efficient, fair, and necessary subsidy to prevent the under-provision of state and local government services.

The Treasury concludes that the itemized deduction for state and local taxes is not required for the accurate measurement of income. ${ }^{46}$ It argues that many of the services provided by state and local government, such as education, roads, and sanitary services, represent personal consumption expenditures; allowing for a deduction for such expenditures would permit taxpayers to finance personal consumption with pre-tax dollars, whereas similar services acquired by private purchase must be paid with post-tax dollars. ${ }^{47}$ The Treasury concedes that many benefits-such as police and fire protection, judicial and administrative services, and public welfare or reliefare not directly analogous to privately purchased goods or services. ${ }^{48}$ Nevertheless, it contends that substantial personal benefit is derived by local taxpayers from these services. These services are generally available to all on the same basis, even though some individuals receive arguably greater benefit than others. In addition, these services are analogous to those provided by the federal government and yet no deduction is allowed for federal taxes.

The Treasury dismisses the argument that state and local taxes should be deductible because they are a compulsory levy. It maintains that rates of taxation are in a sense voluntary because they are controlled through the electoral process. Recent state and local tax reduction initiatives emphasize the potency of this process. The Treasury also indicates that state and local taxpayers can "vote with their feet" by moving to jurisdictions which provide a more personally satisfying combination of public services and taxes. ${ }^{49}$ Such an option is not available at the national level and yet federal taxes are not deductible.

42. Revenue Act of 1978, Pub. L. No. 95-600, \& 111 (a), 92 Stat. 2763, 2777.

43. Surtey, The Federal Income Base For Individuals, in 1 House CoMm. ON WAYS AND MEANs, 86th Cong., 1st Sess., 1 Tax Revision Compendium 1, 10 (Comm. Print 1959) [hereinafter cited as the TAX ReVision Compendium].

44. I TREAs. RePORT, supra note 1 , at 245. The President's Proposals estimate the recoupment of $\$ 33.8$ billion. Pres. Proposals, supra note $\mathbf{3 3}$, at 63 .

45. 1 TREAs. Report, supra note 1 , at $\mathbf{2 4 5}$.

46. Id. at 78 .

47. 2 Treas. Report, supra note 1 , at 62.

48. The President's Proposals also make this concession. Pres. Proposals, supra note 33, at 64.

49. 2 TREAs. RePORT, supra note 1 , at 63. 
The Treasury then assesses the view that the deduction for state and local taxes is a subsidy that reduces the taxpayer's net cost of these taxes. It concludes that there is no reason to believe that expenditures by state and local governments have such strong spillover effects that they would be greatly underprovided but for the federal subsidy. ${ }^{50}$ The Treasury believes that it would be fairer, simpler, and more neutral to have state and local government services financed from after-tax dollars. ${ }^{51}$ It will help to make citizens more conscious of the cost of services provided by state and local government. ${ }^{52}$ Current law discriminates against the alternative to acrossthe-board taxes, that is, imposition of user charges, by making them nondeductible. ${ }^{53}$ By eliminating this discrimination the proposal will facilitate greater use of user charges in appropriate circumstances.

Having concluded that there is no necessity for a federal subsidy, the Report emphasizes that the deduction for state and local taxes is neither an efficient nor a fair subsidy. Since only itemizers receive the deduction benefit, and itemizers represent only about one-third of all families, the Treasury doubts that the subsidy significantly affects the level of state and local government services. ${ }^{54}$ The Treasury contends that the subsidy is unfair both within a state and between states. ${ }^{55}$ It is unfair because the federal government only subsidizes state and local taxes of those who itemize, with the highest subsidy going to those itemizers with the highest federal marginal tax rates. In $1983,95 \%$ of families with incomes over $\$ 100,000$ itemized, while among lower income families there were relatively few itemizers. ${ }^{56}$ Also, because income levels and state and local tax rates vary between states, the federal government subsidizes a greater share of state and local expenditures in high income, high tax states than in low income, low tax states. Deductibility of state and local taxes thus results in a perverse pattern of subsidy distributions both within states and between states. Moreover, because the deduction causes higher federal tax rates for all taxpayers, there is a net benefit only to itemizers and only for states and localities that levy above average taxes.

Support for the deductibility of the various state and local taxes varies. The property tax enjoys the least amount of support, with somewhat more support for a general sales tax and substantially more support for the deductibility of state and local income taxes. The case against deductibility of the property tax is strong because it is perceived as a user charge analogous to

50. 1 Treas. RePort, supra note 1 , at 78 . The President's Proposals reach the same conclusion. Pres. Proposals, supra note 33, at 64 .

51. 2 TrEAs. REPORT, supra note 1 , at 63 .

52. Id. at 80 .

53. Id. at $64-65$.

54. Id. at 78. The President's Proposals also doubt the effect of the subsidy on state and local government services. Pres. Proposal, supra note 33, at 65.

55. I Treas. Report, supra note 1 , at 63 . The President's Proposals also find the deduction unfair to taxpayers within a state and to taxpayers in different states. Pres. Proposals, supra note 33, at 63,65 .

56. 2 Treas. RePORT, supra note 1 , at 64 . 
ordinary personal consumption. ${ }^{57}$ In addition, the deductibility of property taxes discriminates in favor of the homeowner and against the renter, thus many regard the case against deductibility of property taxes as compelling. ${ }^{58}$ Commentators also oppose the deduction of property taxes and general sales taxes because these taxes are regressive, and are made more regressive through a federal tax system that gives the greatest benefit to those who pay the highest marginal rate of tax. ${ }^{59}$

Richard Goode, in disagreement with the Treasury Report, believes that "the best balance between considerations of equity and intergovernmental fiscal coordination would be struck by continuing the personal deduction for state and local income taxes and broad sales and use taxes while eliminating it for property taxes . . . "60 Goode thinks that by allowing deduction of both income taxes and general sales taxes, the federal government would lessen inhibitions on states' greater use of income taxation without exerting pressure on the states to prefer income over sales taxes. ${ }^{61}$

The Treasury recognizes that there are varying amounts of support for the deductibility of the general sales tax, the personal income tax, and the property tax but it rejects the view that itemized deductions should be eliminated for some but retained for others. The reason is the widely differing reliance on these three taxes among the states: five states do not levy a general sales tax, six states do not have a personal income tax, and local governments' reliance upon the property tax varies greatly. ${ }^{62}$ The Treasury concludes that it would be unfair to residents of different states to allow some but not other taxes to be deductible and would distort tax policy at state and local levels. ${ }^{63}$

The Treasury thus concludes that the itemized deduction for all state and local taxes should be phased out. The deduction is not required for the accurate measurement of taxpaying capacity, and it is neither an efficient nor an equitable subsidy. To the extent that any subsidy is warranted, the Treasury contends that direct federal outlays to state and local governments would be more equitable and more cost effective. ${ }^{64}$ Elimination of this itemized deduction will have no direct effect on the revenue of state and local governments. ${ }^{65}$ Indeed, the Treasury notes that because thirty-four state income tax systems piggyback on the federal individual income tax base, and

57. See, e.g., Brazer, The Deductibility of State and Local Taxes Under the Individual Income Tax, in 1 TAx Revision CoMPENDIUM, supra note 43, at 407, 415.

58. Id.

59. Id. at 414

60. R. GoOde, The Individual INCOME TAX 170-71 (1976).

61. Id. at 171 .

62. I TREAS. REPORT, supra note 1 , at 80.

63. 2 Treas. RePort, supra note 1, at 65. The President's Proposals also use the unfairness and distortion argument to support elimination of the deduction. Pres. Proposals, supra note 33, at 6566.

64. 1 Treas. RePORT, supra note 1 , at $78,80$.

65. It will have an indirect effect in that itemizers will be less willing to pay state and local taxes and this will affect that sector's ability to raise revenues. See Noto \& Zimmerman, Limiting State-Local Tax Deductibility: Effects Among the States, 37 NAT'L TAX J. 539, 540 (1984). 
because many of the forty-six states that levy corporate income taxes rely upon the federal corporate tax measurement rules, the Treasury's basebroadening proposals will permit substantial rate reduction by the states. ${ }^{66}$

The Treasury is correct in contending that the deduction for state and local income taxes is not required for accurate measurement of taxpaying capacity. Such capacity is no more affected by income tax paid to a state or local government than it is by income tax paid to the federal government. There is no compelling reason to maintain either that state and local income taxes must be deductible in determining taxable income for the federal income tax or that federal income tax must be deductible in determining taxable income for state and local income taxes. Each can use the same tax base concurrently and make no allowance for the taxes paid to the other level of government without departing from sound tax principles.

Federal deductibility of state income taxes does, however, protect taxpayers against confiscatory taxation. From 1954 to 1963 , the federal marginal tax rate on taxable income in excess of $\$ 400,000$ was $91 \%{ }^{67}$ and one of the highest state marginal tax rate was $10 \%$ in New York. ${ }^{68}$ With federal deductibility, the combined marginal rate of tax on taxable income in excess of $\$ 400,000$ was not $101 \%$ but $91.9 \% .^{69}$ Confiscatory marginal tax rates can also be prevented by state governments making the federal income tax deductible. But confiscatory marginal tax rates are no longer a problem. The Economic Recovery Tax Act of 1981 (ERTA) reduced the top marginal rate from $70 \%$ to $50 \% .{ }^{70}$ The highest marginal state or local income tax rate is now $16 \% .{ }^{71}$ Thus, preventing confiscatory marginal tax rates is a dead issue, particularly in light of the proposal to reduce the highest federal rate to $35 \%$.

There are many in the United States who regard the deduction for state and local income tax as a useful accommodation of federal-state relationships. ${ }^{72}$ There are others who believe that the superior taxing power of the federal government should be used to reduce interstate tax differentials and to allay fears of interstate migration of persons, businesses, and wealth. ${ }^{73}$ Granting deductions from federal taxable income is not the appropriate way to achieve these ends.

State taxpayers who itemize do not bear the full brunt of a state tax increase but are able to pass some of it on to the federal government by

66. 1 TREAS. REPORT, supra note 1 , at 81 .

67. J. Pechman, Federal Tax Policy 298 (3d ed. 1977).

68. Heller, Deductions and Credits for State Income Taxes, in 1 TAX Revision Compendium, supra note 43 , at $419,419-20$.

69. On an additional $\$ 100$, the state tax would be $\$ 10$ and the federal tax would be $91 \%$ of $(\$ 100-\$ 90)$ or $\$ 81.90$ for a total of $\$ 91.90$ or $91.9 \%$.

70. Pub. L. No. 97-34, \& 101, 95 Stat. 172, 176 (1981) (codified at I.R.C. \& 1) (Lawyers Co-op. 1984).

71. Advisory Commission on Intergovernmental Relations, Significant features of Fiscal Federalism 60 (Table 47) (1984) [hereinafter cited as Fiscal Federalism].

72. Due, Personal Deductions, in Compenensive Income Taxation 37, 50-51 (J. Pechman ed. 1977).

73. R. Goode, supra note 60 , at 170 . 
deducting those taxes in the calculation of federal taxable income. The diminished federal tax revenue forces the federal government either to increase taxes, decrease expenditures, or permit its deficit to grow. If Congress raises taxes, a state that increases its taxes will export part of the tax burden from the state to the national body of taxpayers. The burden is shifted from the itemizers in a state that increases taxes to all other taxpayers in the nation, including nonitemizers within that particular state. The exportation of tax burden from a state will be relatively more successful 1) the higher the proportion of taxpayers in the state who itemize, 2) the higher the average income of the taxpayers in the state, and 3) the more the tax increase is concentrated upon taxpayers having higher marginal federal income tax rates. Thus, two states that levy the same average tax per taxpayer will realize different federal tax subsidies. If everything else is equal, the federal subsidy will be greater in the state with the more progressive state tax structure. The federal deductibility of state and local taxes creates a bias in favor of the income tax over sales and property taxes, and a bias in favor of a progressive income tax over a proportional income tax.

I am sympathetic to the view that it is preferable for state and local governments to obtain greater revenue from income taxation than from sales or property taxes. There is a good deal of truth in Galbraith's thesis that in the United States there is private affluence and public want. ${ }^{74}$ Galbraith contends that there is a lack of balance between privately produced and marketed goods and services, and publicly provided services. ${ }^{75}$ Neoconservatives would, of course, deny the validity of Galbraith's private opulence and public squalor thesis and are intent on further reducing the level of government-provided public services. Although I regard the neoconservatives as misguided, I cannot endorse a system that provides a perverse pattern of federal subsidies running counter to the customary goal of reducing interstate inequality of income.

Federal deductibility of state and local taxes is tantamount to a system of state-initiated revenue sharing. ${ }^{76}$ Unfortunately, the ability of states to benefit from this kind of revenue sharing differs widely. Throughout the nation, $33.4 \%$ of all taxpayers itemized in 1982 , but the percentage varied from a low of $17.7 \%$ in West Virginia to a high of $45 \%$ in Utah. ${ }^{77}$ Average per capita income for the nation in 1982 was $\$ 11,113$, but this varied from a low of $\$ 7,733$ for Mississippi to a high of $\$ 16,854$ for Alaska. ${ }^{78}$ Federal tax saving from the deductibility of state and local taxes has been estimated by states for 1984. The highest federal tax saving per capita occurred in New York (\$263), followed by Maryland (\$211) and Massachusetts (\$195); whereas the lowest

74. J. Galbratth, The Affluent Society 232-43 (3d ed. 1976).

75. Id. at 232.

76. See, e.g., Keller, The Case for Highly Graduated Rates in State Income Taxes, 35 MD. L. Rev. 617 (1976); Moscovitch, State Graduated Income Taxes-A State Initiated Form of Revenue Sharing, 25 NAT'L TAX J. 53 (1972).

77. 2 TrEAs, RePORT, supra note 1 , at 67.

78. Id. 
saving occurred in South Dakota $(\$ 33)$ and Tennessee $(\$ 33)$, followed by Louisiana (\$34). ${ }^{79}$ Thus, the average per capita federal tax saving from the deductibility of state and local taxes was eight times greater in New York than it was in South Dakota and Tennessee. Mississippi with the lowest per capita income of all the states obtained an average per capita federal tax saving of $\$ 45$, or only $17.1 \%$ of that of New York. The federal subsidy is greater for the high tax states whose citizens have higher per capita income. This distribution of the subsidy is not appropriate and thus the Treasury's proposal to end the deductibility of state and local taxes has merit.

The federal government does have superior taxing power for the simple reason that it levies taxes on the whole nation. As there is greater mobility among the states than with other nations, states must be sensitive to the problem of interstate migration of persons, wealth, and industry. Walter Heller has described the cushioning or muting effect of interjurisdictional tax differentials as the greatest strength of the federal deductibility of state and local taxes, but he regards its distribution as its greatest weakness because "the higher the income, the deeper the cushion." 80 In 1959, he proposed a tax credit as a substitute for deductibility. ${ }^{81}$ The deduction from federal tax payable was to be equal to the lesser of the state and local income taxes paid or $5 \%$ of the federal tax payable. This tax credit would be available to all taxpayers whether itemizers or nonitemizers. Such a tax credit would materially improve the distribution of benefits by income groups-increasing the benefit to lower bracket taxpayers and diminishing the benefit to those in the higher bracket. The credit would also reduce substantially the perverse pattern of federal tax subsidies among the states currently produced by the deductibility of state and local taxes. The net effect of substituting a flat $5 \%$ credit for the deductibility of state and local taxes would be a shift in the federal subsidy from the wealthier to the poorer states.

Walter Heller noted that a flat credit with a cap equal to $5 \%$ or even $10 \%$ of the federal tax payable "would not remove the interstate competition threat entirely, but it would put a substantial noncompetitive floor under State income taxes and reduce the struggle for competitive advantage which has retarded the use of the outstanding growth tax in the State revenue system." 82 One of the difficulties with this proposed credit is that the six states which do not levy an income tax and the three states with a very limited income tax would be coerced or strongly induced to impose a personal income tax sufficient to absorb the federal credit. But if the case for state taxation of income is strong, federal inducement to levy an income tax should not be required.

79. Advisory Comm'n on Intergovernmental Relations, Strengthening the Federal Revenue System: Implications for State and local Taxing and Borrowing, inside back cover (1984) [hereinafter cited as IMPLICATIONS for State and Local TAXING].

80. Heller, supra note 68 , at 422.

81. Id. at $423-27$.

82. Id at 425 . 
An inducment to levy a state income tax would also run counter to current public opinion. In a survey which asked: "Suppose your state government must raise taxes substantially, which would be a better way to do it?," $57 \%$ replied state sales tax, 23\% replied state individual income tax, and 20\% responded "don't know." 83 Even though public opinion may be misguided, tax reformers might be unwise to induce a tax change which runs counter to current opinion. It should also be recognized that the general stimulus to state and local tax increases and spending caused by the current deductibility of state and local taxes conflicts with the post-Proposition thirteen world in which nineteen states have state-level and forty-one states have local-level tax or expenditure limits. ${ }^{84}$

In addition to proposals that would eliminate deductibility of one or all of the currently deductible state and local taxes, a number of suggestions have been made to restrict deductibility. One proposal would make state and local taxes deductible only to the extent that tax payments exceed a floor set as a percentage of adjusted gross income. A second proposal would make state and local taxes deductible only up to a ceiling set as a percentage of adjusted gross income. A third proposal would disallow a percentage of currently deductible tax payments. Noto and Zimmerman conclude that if state and local tax deductibility is to be limited, their preferred method is to limit deductibility to state and local taxes that exceed a floor set as a percentage of adjusted gross income. ${ }^{85}$ Their preference is based on two criteria, one of which is interstate equity - the limitation should be evenhanded in allocating increased federal tax liability among itemizers in all states. ${ }^{86}$ However, if the present federal tax subsidy is distributionally perverse, precisely what one does not want is an evenhanded allocation of the increased federal tax liability. In any case, there is more reason to be concerned about the total distributional impact of all the proposed tax changes than about the distributional impact on individuals flowing from one tax change.

The Treasury proposal to phase out the deductibility of all state and local taxes is warranted. This change would make the tax systems of the United States and Canada more similar. If a Canadian province or local government increases its taxes, the taxpayer bears the full brunt of the tax increase. If state and local taxes are made nondeductible, the same would be true in the United States. However, in Canada there will be a small secondary effect flowing from the increase in provincial taxes. Since 1957, equalization payments have been paid by the Canadian federal government to the poorer provinces so that they will have sufficient revenue to provide comparable levels of public service at reasonably comparable levels of taxation. The current Canadian formula for calculating equalization payments is based on

83. Fiscal Federalism, supra note 71 , at 91.

84. Implications fOR State and Local TAXING, supra note 79 , at 38.

85. Noto \& Zimmerman, supra note 65 , at 546 .

86. Id. at 546-47. The second criterion is the response of state and local government's ownsource tax revenue to the proposals. Id. 
the concept of a national average rate of tax determined for each of thirtythree revenue sources of the provinces. ${ }^{87}$ The per capita yield for each revenue source is determined for each province by applying the national average tax rate to that province's own tax base and then dividing that hypothetical tax revenue by the province's population. The per capita yield from each revenue source for each province is compared with the average per capita yield in the five provinces constituting the standard.88 The per capita deficiency or excess for all thirty-three sources is aggregated and a province with a net per capita deficiency will be entitled to an equalization grant equal to its net per capita deficiency multiplied by its own population. Thus, in Canada, when provinces increase their rates of taxation, the national average tax rate will be increased with the result that equalization payments will be increased to provinces whose tax capacity is lower than the five-province standard. This may cause the federal government to increase its level of taxation to finance the increased equalization payments. Section 36(2) of Canada's new Constitution recognizes this commitment to the principle of equalization. ${ }^{89}$

In the United States, the same commitment to the principle of equalization is not found. Yet the need for such equalization is as great, if not greater, in the United States as in Canada. A reasonable first approximation of a state's fiscal capacity is given by its per capita income. There is even wider divergence between states with the highest and lowest average per capita income in the United States as compared with the divergence between Canadian provinces. ${ }^{90}$ There has been a dramatic growth, particularly in the last decade, in the United States' federal grants to state and local

87. Canadian Tax Foundation, The National Finances 1982-83, at 173-75 (1983).

88. The five provinces are British Columbia, Manitoba, Ontario, Quebec, and Saskatchewan. Id. at 174 .

89. Canada Act 1982, ch. 11, pt. III, \& 36(2), 1980-1983 Can. Stat. iii, xiii-xiv states:

Parliament and the government of Canada are committed to the principle of making equalization payments to ensure that provincial governments have sufficient revenues to provide reasonably comparable levels of public services at reasonably comparable levels of taxation." 90 .

TABLE 1

Personal Income Per Capita, 1983

$\begin{array}{lrrlrr}\text { United States } & \$ 11,675 & \% & \text { Canada } & \$ 13,541 & \% \\ \text { Alaska } & \$ 16,812 & 144 & \text { Ont. } & 14,784 & 109 \\ \text { Conn. } & 14,826 & 127 & \text { Alta. } & 14,652 & 108 \\ \text { N.J. } & 14,057 & 120 & \text { B.C. } & 14,339 & 106 \\ \text { Cal. } & 13,239 & 113 & \text { Sask. } & 12,686 & 94 \\ \text { N.Y. } & 13,146 & 113 & \text { Man. } & 12,603 & 93 \\ \text { Ark. } & 9,040 & 77 & \text { Que. } & 12,531 & 93 \\ \text { Utah } & 9,031 & 77 & \text { N.S. } & 10,889 & 80 \\ \text { S.C. } & 8,954 & 77 & \text { P.E.I. } & 10,056 & 74 \\ \text { W. Va. } & 8,937 & 77 & \text { N.B. } & 10,040 & 74 \\ \text { Miss. } & 8,072 & 69 & \text { Nfld. } & 9,179 & 68\end{array}$

Source: U.S. Dep't of Commerce, Bureau of the Census, Statistical Abstract of the United States: 1985, at 440 (Table 731) (1984); Statistics Canada, National. InCome and EXPENDItUREs AcCounts, 1969-1983, at 46-47 (Table 36) (1984). 
government. ${ }^{91}$ There are many categorical grants and block grants. In 1972, general revenue sharing was introduced to provide unrestricted and nonmatching grants to state and local governments. ${ }^{92}$ Professors Richard and Peggy Musgrave have concluded that: "General revenue sharing is an effective means of transferring tax burden from the state-local to the federal revenue system, but it has not been of major importance in equalizing fiscal capacity and need."93 They also conclude that "traditional categorical grants have not been effective as a means of fiscal equalization."94 The Musgraves are not disturbed by the very limited amount of equalization achieved through federal grants, however. They believe that a grant distribution inversely related to a state's per capita income is not an effective approach because high income states frequently contain low income jurisdictions and intrastate differentials in fiscal capacity are greater than interstate differentials. ${ }^{95}$ The response to this argument would seem to be that a high income state containing low income pockets has, within itself, the fiscal capacity to provide all its citizens with adequate governmental services. The low income state, however, without equalization grants from the federal government, will be powerless to provide adequate government services to its citizens unless it is prepared to impose unduly high levels of taxation.

In 1982, among all the states, Mississippi had the lowest per capita income $(\$ 7,733)$ and Connecticut had the second highest $(\$ 13,939)$, more than $80 \%$ higher than Mississippi. ${ }^{96}$ The fiscal capacity of Mississippi is thus much less than that of Connecticut and one would expect that governmental expenditures on services in Mississippi would be much lower than in Connecticut. For example, in 1981-82, the current expenditure per pupil in average daily attendance in public elementary and secondary schools was $\$ 1,706$ in Mississippi and $\$ 3,189$ in Connecticut, or $\mathbf{8 6 . 9 \%}$ higher than in Mississippi. ${ }^{97}$ The percentage of the population having completed one to three years of high school in Connecticut is $83.7 \%$ but only $73 \%$ in Mississippi; the percentage of the population having completed one to three years of college is $35.9 \%$ in Connecticut and $25.6 \%$ in Mississippi. ${ }^{98}$ The infant mortality rates per thousand live births is 19.1 and 10.2 respectively for the black and white populations of Connecticut, but is 23.7 and 11.1 in

91. R. Musgrave \& P. Musgrave, Public Finance in Theory and Practice 552-54 (3d ed. 1980).

92. Id. at 558-59.

93. Id. at 566 .

94. Id.

95. Id.

96. 2 TREAS. REPORT, supra note 1 , at 67 . The reason I have compared Mississippi, the state with the lowest per capita income, with Connecticut, the state with the second highest per capita income, rather than with Alaska which has the highest per capita income, is that the cost of living is substantially higher in Alaska and this would distort the comparison.

97. U.S. Dep't of Education, The Condrtion of Education: 1984 Edition 40 (Table 1.14) (1985).

98. U.S. Dep't of Commerce, Bureau of the Census, Statistical Abstract of the Unrted STATES: 1984, at 145 (1983) (statistics from 1980). 
Mississippi.99 Thus, Mississippi's infant mortality rate for blacks is $24 \%$ higher than Connecticut's and is $\mathbf{8 . 8 \%}$ higher for whites. There can be little doubt that the ability of Mississippi to provide governmental services for its citizens is substantially less than that of Connecticut. Equalization payments from the federal government would seem to be necessary for lower income states such as Mississippi.

Professor Kenneth Dam has stated that:

[T] hey [state and local governments] continue to pursue widely different expenditure policies in such basic areas as education and transportation, and there has been no serious attempt to equalize revenues among the states. Whatever the state of health of federalism generally, fiscal federalism is still very much alive. ${ }^{100}$

To a Canadian, equating the lack of any serious attempt to equalize fiscal capacities of the states with vigorous fiscal federalism seems peculiar. If fiscal capacities were equalized, a state would still be able to pursue widely different expenditure policies but would be able to provide an average standard of governmental service with only an average level of taxation should the state choose to do so. The lack of a serious commitment to equalization would be regarded by most Canadians, not as an affirmation of fiscal federalism, but as a denial of the rights of all citizens to comparable levels of governmental service at comparable levels of taxation.

The Treasury's proposal to phase out the deduction of state and local taxes is appropriate because the current deduction magnifies rather than reduces the difference in the fiscal capacities of the states. The President, in his 1986 Budget, has proposed the elimination of general revenue sharing. ${ }^{101}$ A preferable policy might be to continue general revenue sharing after it has been wholly revamped to achieve greater equalization of the fiscal capacities of the states.

\section{B. Termination of the Alternative Minimum Tax}

The Treasury Department proposes to abolish the alternative minimum tax. This is particularly interesting for Canada because in last year's federal election all three major political parties advocated some form of minimum tax. The United States' alternative minimum tax was originally enacted as part of the Tax Reform Act of 1969.102 It was considered necessary because "many individuals and corporations did not pay tax on a substantial part of their economic income as a result of the receipt of various kinds of tax-favored income or special deductions." 103 The Treasury notes that the existence of a minimum tax reflects an ambivalence about the tax preferences which are made liable to the minimum tax. It also reveals significant skepticism about

99. Id. at 77 (statistics from 1980).

100. Dam, The American Fiscal Constitution, 44 U. CHI. L. Rev. 271, 320 (1977).

101. Executive Office of the President, Office of Management and Budget, Budget of THE UNTted States Government, 1986, at 5-151 (1985).

102. Pub. L. No. 91-172, \& 301, 83 Stat. 487, 580-86 (1969).

103. 2 TREAS. RePORT, supra note 1 , at 113. 
the fairness and efficiency of tax preferences, as well as about the justification for the higher tax rates to offset revenue loss. ${ }^{104}$

A tax system which offers taxpayers a rich smorgasbord of tax preferences is bound to create problems, for it results in the abandonment of horizontal equity. Taxpayers with the same economic income are taxed at greatly differing rates. Those earning the bulk of their income from nonpreferred activities pay higher taxes than others whose economic income is the same but is received in the form of capital gains or income from real estate or natural resources that benefit from tax preferences. There is really only one satisfactory approach to the present tax preference smorgasbord-eliminating virtually all of them. Tax should be levied on a comprehensive income tax base. This was the message of Canada's Carter Report, and it is also the verdict of the Treasury Report. The Treasury Department seeks to redefine the income tax base so as to approximate more closely economic income and concludes that, if its proposals were fully implemented, the alternative minimum tax would be unnecessary. It suggests that this tax be repealed for taxable years beginning on or after January 1, 1990, but only if its basebroadening proposals are accepted. ${ }^{105}$ The Treasury notes that between 100,000 and 200,000 individuals are currently subject to the flat $20 \%$ minimum tax, but that several million taxpayers become involved in the complexity of the alternative minimum tax because they must make calculations in order to determine whether they are liable. ${ }^{106}$

The alternative minimum tax is a very poor second-best approach to the equity problem posed by current tax preferences. It is really an admission of failure-an admission that Congress or Parliament cannot withstand the heat that would be generated by tax lobbyists who would oppose a truly comprehensive income tax base. In my opinion, Canada should hesitate before making such an admission. Canada should decline to follow the American example of a minimum tax, particularly now that the U.S. Treasury Department doubts the wisdom of this approach and is advocating its repeal. The fact that some taxpayers overindulge themselves at the tax preference smorgasbord, and as a result pay little or no tax, is indeed a serious problem which must be addressed. ${ }^{107}$

104. Id. at 114.

105. Id.; 1 Treas. RePort, supra note 1 , at 130. The President's Proposals retain the alternative minimum tax of $20 \%$. Alternate minimum taxable income would be the sum of adjusted gross income and preference items in excess of $\$ 10,000$ ( $\$ 5,000$ for married persons filing separately) and subtracting certain deductions and exemptions. Pres. Proposals, supra note 33, at 330. Thirteen preference items are listed. Id. at $\mathbf{3 3 0 - 3 2}$.

106. Treas. Report, supra note 1 , at 114. The President's Proposals address this concern by excluding the taxpayer's first $\$ 10,000$ of preferences from the alternative minimum tax, thus "only individuals using substantial amounts of the preferences would need to compute the minimum tax." Pres. Proposals, supra note 33, at 332.

107. In 1981 , of the 5,800 Canadians who had incomes in excess of $\$ 250,000,239$ paid no income tax. These 239 individuals had an average income of $\$ 615,305$; this should be compared to an average income of $\$ 442,301$ for the 5,561 Canadians who paid an average of $\$ 133,528$ in tax. See Canada Dep't of Supply \& Services, 1983 Taxation Statistics 59, 81 (1983). 
The Minister of Finance, Michael Wilson, in an address to the Canadian Tax Foundation, recognized that respect for the tax system was being undermined because the system permits a significant number of high income Canadians to pay either no, or unacceptably little, personal income tax. ${ }^{108} \mathrm{He}$ acknowledged that the reason for this was the growing range of tax incentives introduced over the years. Individually, these incentives were defended as having "served useful and beneficial economic and social ends," 109 but their combined impact he regarded as another question, one which has aroused public concern.

The Finance Minister suggested two broad approaches to the problem, a targeted and a comprehensive approach. ${ }^{110}$ Under the targeted approach, limits would be placed on specific tax provisions most heavily used by high income persons to avoid paying tax. Because a limited range of tax incentives account for a very large proportion of nontaxable returns of high income individuals, targeted restrictions would appear to be warranted. This approach, according to the Minister, poses two problems. ${ }^{11}$ The first is that targeted restrictions might just stimulate greater use of other nonrestricted tax preferences, which would generate a call for another round of specific limitations in a few years' time. The second problem is that this approach does not address the preferences' combined impact which permits high income persons to avoid paying their fair share of income tax. This problem suggests the second approach, which is to define income more comprehensively for the purpose of levying a minimum tax. The chief difficulty with this approach is the complexity involved in redefining the income base for such a minimum tax. Achieving a comprehensive and refined measure of income would be tantamount to rewriting the Income Tax Act.

Achieving fairness without undermining the incentives for investment and without unduly complicating tax returns for all Canadians is indeed a challenge. However, calling it a challenge suggests that there is a satisfactory solution. It might be better to call it a dilemma, for neither a targeted nor a comprehensive approach constitutes an adequate response. A much more fundamental approach to this conundrum seems to be required. I believe that the Minister senses that this is the case, for he has questioned whether "the goal of economic growth would be better served by fewer rather than more industrial incentives." 112 The adoption of a comprehensive and neutral tax system might not only promote economic growth by permitting market forces to direct resources to their most productive uses freed from tax distortions, but might also enhance horizontal equity and restore taxpayer confidence in the integrity of the income tax system. The minimum tax is but a very

108. Address by the Honorable Michael Wilson, Minister of Finance, to the Canadian Tax Foundation, in Toronto, Canada, at 8 (November 28, 1984) (Press Release of the Canada Department of Finance).

109. Id.

110. Id. at 9 .

111. Id. at 9 .

112. Id. at 4. 
inadequate palliative. Moreover, a flat rate minimum tax has no legitimate place in an equitable and progressive income tax structure whether the highest marginal tax rate is $50 \%$ or the $35 \%$ advocated in the Treasury Report. Both the United States Congress and the Canadian Parliament should have the gumption to redefine the income tax base so that it comes to resemble the Haig-Simons definition of income much more closely.

The Treasury Report notes that " $[\mathrm{t}] \mathrm{ax}$ reform has often-and long-been held hostage by failure to deal with transitional issues ...."11s The Treasury has suggested a number of mechanisms that will ease the impact of windfall gains and losses and of economic dislocation that is an unavoidable concomitant of tax reform and will enhance the political feasibility of reform so as to promote a fair and orderly transition. These include postponement of the effective date of the tax change, phasing in the change over time, and grandfathering income from certain assets so that the new provisions apply only to new purchasers. ${ }^{114}$

The Report does not acknowledge that the minimum tax might be the most suitable mechanism to facilitate the transition from a narrow-based to a broad-based income tax. This mechanism would involve setting up a second tax system to parallel the existing system. ${ }^{115}$ The minimum tax would be levied on a new comprehensive income base, and a taxpayer would be required to pay whichever income tax amount is greater, computed either by the existing or the minimum tax system. To minimize the disruptive impact of fundamental tax reform upon persons who have made investments or otherwise relied upon existing tax concessions, the minimum tax could be phased in gradually. For example, if a three-bracket system with rates of $15 \%$, $25 \%$, and $35 \%$ were considered appropriate for a comprehensive income tax system, the initial rate structure for the minimum tax might be $1.5 \%, 2.5 \%$, and $3.5 \%$. Over a period of ten years, the initial rates could be increased in equal annual increments of $1.5 \%, 2.5 \%$, and $3.5 \%$ until the desired schedule of $15 \%, 25 \%$, and $35 \%$ was achieved. As the rate schedule for the minimum tax is gradually increased, more and more taxpayers would begin to pay the minimum tax, and the additional tax revenue so derived would permit the rate structure of the original tax system to be reduced. Thus, over a period of ten years, all taxpayers could pay the minimum tax levied on a comprehensive income tax base, and the original tax system could be abandoned. The minimum tax as a transitional mechanism probably merits consideration for only a truly comprehensive tax reform agenda which includes taxing of interest on all state and local government bonds and making mortgage interest on homes nondeductible. For the kind of reform it proposed, the Treasury's transitional provisions are probably adequate.

113. 1 Treas. Report, supra note 1 , at 19.

114. Id. at 20.

115. Richard D. Hobbet proposed the minimum tax as a mode of facilitating tax reform in Transitional Mechanisms to Facilitate Tax Reform, 34 LAw \& CoNTEMP. PROBS. 818 (1969); see also Graetz, The 1982 Minimum Tax Amendments As a First Step in the Transition to a "Flat-rate" Tax, 56 S. CAL. L. REv. 527 (1983). 


\section{Inflation-Proofing of the Tax System}

Another aspect of the Treasury proposal of great interest to Canadians is the "inflation-proofing" of the income tax system and the centrality accorded to it. This is one significant way in which the Treasury proposal and the Carter Report differ. The Carter Report was adamantly opposed to any automatic adjustment for inflation, whether dealing with the mismeasurement of tax liability caused by bracket creep or the mismeasurement of income itself caused by treating historical dollars as equivalent to current dollars. ${ }^{116}$ The Carter Report was somewhat crudely characterized by the expression-a buck is a buck is a buck. While the Treasury Report also generally endorses this approach, it emphasizes that inflation causes dollars of different time periods to have different purchasing power and that a fair income tax system must address this problem. ${ }^{117}$

It should be recognized that the Carter Royal Commission was examining Canada's tax system in the mid-1960's, at a time when the rate of inflation was projected to be between $1.5 \%$ and $2 \%$ per year. ${ }^{118}$ At the time, minimizing the cumulative effect of such a relatively mild rate of inflation seemed reasonable, as was concluding that concern about taxing illusory gains was being overemphasized. The commissioners also concluded that comprehensive inflation adjustment would be extremely complex and that it would be inappropriate to relieve only some groups from the impact of inflation. ${ }^{119}$ The commissioners further believed that indexation of the tax system would be a serious error because it "would impair the power of the tax system to stabilize the economy." 120 Henry Simons, the intellectual father of the Carter Report, ${ }^{121}$ had concluded that "any attempt to allow systematically for monetary instability in the measurement of taxable income seems altogether inexpedient ..."122 It was therefore to be expected that inflation-proofing the tax system would be omitted from the tax reform agenda at that time.

Inflation has been viewed as a much more serious problem with the extended inflationary period during the late 1970's and the early 1980's. In spite of substantially higher nominal interest rates, some investors experienced negative real after-tax rates of return. The lack of indexation of the tax base means that inflation imposes a surtax on investment income at the same various rates now applicable to those investments-ordinary rates

116. 2 CARTER REPORT, supra note 8, at 32-34.

117. See 1 Treas. Report, supra note 1 , at 6 . The President proposes indexation of the earned income credit, Pres. Proposals, supra note 33, at 17-18; depreciable assets, id. at 132-59; inventory, id. at 174-78; and capital gains (starting in 1991, at the option of the individual taxpayer), id. at 164 73.

118. 2 CARTER Report, supra note 8, at 32.

119. Id. at 33 .

120. Id. at 47.

121. The intellectual debt owed to Henry Simons by the Royal Commission was acknowledged by its chairman, Kenneth LeM. Carter, in an article entitled Canadian Tax Reform and Henry Simons, 11 J.L. \& ECON. 231 (1968).

122. H. Simons, Personal Income Taxation 206 (1938). 
on bonds, the preferential rate on realized long-term capital gains, and at a zero rate on unrealized capital gains. The nonneutral taxation of business income across assets and industries is capriciously distorted by inflation, with the result that business planning becomes even more uncertain. Full deductibility by the borrower of the high nominal interest payments during periods of inflation greatly enhances the opportunity for tax arbitrage-the process of borrowing to purchase tax-preferred assets. There is a growing realization that tax arbitrage may well be the most critical tax reform issue facing us today. ${ }^{123}$

Piously hoping for price stability is no longer an adequate response to the problem that inflation poses for a fair income tax system. Inflation increases the distortions caused by the current tax system. Full indexation of the tax system was previously opposed because it was thought that the automatic economic stabilizing effect of the income tax system would be seriously impaired. It is now recognized that even with full indexation there would be significant adjustment lags and that the automatic stabilizing effect of an indexed tax system compared with a nonindexed system would not be significantly different and should not deter the adoption of an indexed tax system. ${ }^{124}$ It seems appropriate, therefore, that the Treasury Report should set as its goal a much more comprehensive income tax system which would be largely inflation-proof.

Inflation may distort the determination of income tax liability in two main ways: bracket creep, which affects all kinds of income; and incorrect measurement of investment and business income, which affects only income from capital. Canada, since $1974,{ }^{125}$ and the United States, since 1985,126 have removed the problem of bracket creep through indexation of personal exemptions and tax brackets. Taxpayers whose nominal income merely increases by the rate of inflation will no longer find their after-tax real income diminished. Inflation will neither erode the value of their personal exemptions nor narrow the width of tax brackets. Indexing of the rate structure has a further advantage over periodic ad hoc adjustment, for it compels legislators to vote openly for tax increases and ends the "practice of palming off discretionary adjustments to counter-balance inflation as 'tax cuts.' "127 Without indexation, the larger a taxpayer's personal exemption entitlement, the greater was his exposure to inflation induced tax increases. Thus, the larger the number of one's dependants, the greater was the inflation induced tax increases, "a result that would be sensible only were it assumed

123. Steuerle, Tax Arbitrage, Inflation, and the Taxation of Interest Payments and Receipts, 30 WAYNE $\mathrm{L}$. REv. 991, 1009 (1984).

124. H. Aaron, Inflation and the Income Tax 313-14 (1976).

125. Ch. 30, \& 15, 1973-1974 Can. Stat. 441, 452-55 \& 117.1 (adding to the Income Tax Act).

126. I.R.C. \& 1(f) (Lawyers Co-op. 1984). This provision is closely modelled after the Canadian section 117.1 even to the selection of September 30 for comparing the Consumer Price Index. See Income Tax Act, ch. 140, \$ 76(3), 1980-1983 Can. Stat. 3777, 3955-56.

127. Rosenn, Adjusting of Business Income for Inflation: Lessons from Brazil and Chile, 13 TEx. INT'L L.J. 165, 195 (1978). 
that families with children had their relative spending power improved in periods of general price inflation."128 Indexing cures such problems.

Indexing the rate structure is not as important as the inflation adjustments necessary to prevent the mismeasurement of business and capital income. Periodic adjustment of personal exemptions and of the rate structure can achieve results comparable to those of indexing but cannot correct for income mismeasurement. Even so, since indexing the rate structure can be achieved with comparative ease, it is not surprising that it precedes the more difficult task of preventing inflation from causing mismeasurement of capital income. Although indexing the rate structure only begins this year in the United States, the Treasury Report says that it "should remain an inviolate part of the tax system." 129 In Canada, there may be some doubt that such indexing has become "an inviolate part" of its tax system. The 1981 budget placed a $6 \%$ indexation cap on inflation adjustment for 1982, followed by a $5 \%$ cap for 1983. ${ }^{130}$ An Advisory Committee Report to the Minister of Finance (the Lortie Report) criticized the two-year limitation upon full indexation of personal exemptions and tax brackets because it gave "conflicting and confusing signals about the extent of the government's commitment to removing the effects of inflation."131 The temporary retreat from full indexation of the rate structure can only be partially justified as a means of breaking the inflation psychology taking root. Professor Gillespie perceives a shrewd and politically sensitive attempt by the Department of Finance and the government to eliminate the rate structure indexation in the 1981 budget. ${ }^{132}$ While his hypothesis that "the government used the 1981 budget proposals as a strategic device to divert opposition from the eventual de-indexing reform"133 is not convincing, neither the Canadian government nor the Department of Finance has issued a ringing declaration proclaiming rate structure indexation an "inviolate part of the tax system" as has the Treasury Department. ${ }^{134}$

Canada, like most other nations, has made no comprehensive or systematic effort to correct the mismeasurement of capital income caused by inflation. The Department of Finance has taken the position that comprehensive corrections for all the tax-related effects of inflation would not

128. Bossons \& Wilson, Adjusting Tax Rates for Inflation, 21 Canadian TAX J. 185, 188 (1973).

129. 1 TREAs. REPORT, supra note 1 , at 17.

130. Income Tax Act, ch. 140, $\$ 76(3), 1980-1983$ Can. Stat. 3777, 3955-56 (adding subsection $117.1(7.1))$.

131. Canada, Dep't of Supply \& Services, Report of the Ministerial Advisory Commttee on Inflation and the Taxation of Personal InVestment Income 10 (1982) [hereinafter cited as the LORTIE REPORT].

132. Gillespie, The 1981 Federal Budget: Muddling Through or Purposeful Tax Reform?, 31 Canadian TAX J. 975, 984-87 (1983).

133. Id. at 988.

134. The budget of May 23, 1985 will greatly curtail indexation of personal exemptions and tax brackets in Canada. Adjustments will only be made to the extent that the annual increase in the consumer price index exceeds three percent. Canada, Dep't of Finance, Budget Papers-Securing ECONOMIC RENEWAL 73 (1985). 
be feasible at the present. ${ }^{135}$ The Lortie Report questioned whether it was feasible for Canada alone to implement an inflation corrected system for the taxation of business income, given the close integration of the Canadian and American economy. ${ }^{136}$ Seeing the U.S. Treasury propose comprehensive measures to correct the mismeasurement of income from capital caused by inflation is therefore encouraging. This will encourage Canadians to do the same, for Canada will no longer have to fear being out of step with what is done in the United States. The Treasury's advocacy of a comprehensive approach is also to be lauded because Canadian and American experiences with ad hoc measures to minimize the impact of inflation have not been happy. The $\$ 1,000$ deduction for investment income of individuals, the twoyear write-off for manufacturing and processing equipment, the investment tax credit, the 3\% inventory allowance and the Indexed Security Investment Plan do not represent a satisfactory Canadian response to the problem of inflation. ${ }^{137}$

Inflation results in a mismeasurement of income whenever dollars of different time periods are treated as equivalent. If two capital assets, $A$ and $B$, were each acquired for $\$ 1,000$ and were each sold for $\$ 2,000$, but $A$ was purchased twenty years ago and $B$ was purchased last year, it is immediately apparent that the equal nominal gain of $\$ 1,000$ realized on each asset bears little real relationship to each other. In an inflationary world, it is also true that sales revenue of $\$ 100$ on January 1 is not an exact equivalent of sales revenue of $\$ 100$ on December 31 of the same year. Nevertheless, the significant distortion flowing from inflation occurs through treating dollars of a different year as equivalent to current dollars. The major distortions are generally considered to occur in the following four specific areas:

1. Capital Gains-Proceeds of disposition are expressed in current dollars but the basis is expressed in historical dollars. Gains in nominal terms are therefore larger than real gains which can be negative and losses in nominal terms understate real losses.

2. Depreciation-Depreciation claims are based on historical costs but the revenues against which the assets are written off are measured in current dollars. Depreciation, in the absence of investment incentives, is therefore understated in real terms.

3. Inventory-Where the first goods put into inventory are considered the first out (FIFO), the deduction for cost of goods used or sold is based on lower prices that prevailed earlier. If cost of goods is understated, profit is overstated.

4. Debt-Debt is denominated in historical dollars and is repaid in current dollars. The creditor suffers a loss in real terms and the debtor has an identical real gain. Also all interest receipts or payments are taxed as income or are deducted from income even though a substantial portion may represent an inflation adjustment.

135. LORTIE REPORT, supra note 131 , at 43.

136. Id. at 43-44.

137. These adjustments for inflation are unsatisfactory because they are only partial measures when overall adjustment is required. The budget presented on May 23, 1985 proposed to repeal the indexed security investment plan as of January 1, 1986. Canada, Dep't of Finance, Budget Papers-Securing Economic Renewal 5 (1985). 
The Treasury proposal dealing with each of these four areas will be described briefly and discussed under the same four headings.

1. Capital Gains. The Treasury proposes that the cost basis of capital assets be indexed for inflation to avoid taxing nominal gains that merely reflect inflation, ${ }^{198}$ and that real capital gains be taxed as ordinary income when realized. ${ }^{139}$ The Treasury notes that the current exclusion of $60 \%$ of longterm nominal capital gains is an exceedingly inaccurate mode of adjusting for inflation. ${ }^{140}$ With high rates of inflation and a long holding period, the exclusion is inadequate; and with low rates of inflation and a short holding period, the exclusion is far too generous.

For property other than inventory or debt instruments, a taxpayer's original cost basis would be indexed for inflation during the holding period. ${ }^{141}$ An asset would have to be held for one full calendar quarter in order to qualify for indexing. ${ }^{142}$ The Internal Revenue Service proposes to publish inflation tables based upon the Consumer Price Index for Urban Households which would specify the inflation adjustment factor to be applied to the original cost basis to determine the inflation-adjusted basis. ${ }^{143} \mathrm{~A}$ taxpayer, knowing the quarter of the year in which the asset was purchased as well as the quarter of the year in which the asset was sold, would locate a single inflation adjustment factor. These factors would be computed by the Internal Revenue Service using a half-quarterly convention, which would allow only half the applicable quarterly inflation rate regardless of when an asset was acquired or sold during the quarter. ${ }^{144}$

The tables would contain inflation adjustment factors back to the first quarter of $1965 . .^{145}$ Assets acquired before 1965 would be indexed as if acquired on January 1,1965 . The Treasury obviously wishes to limit the size of the table of inflation adjustment factors, pointing out that $84 \%$ of the inflation during the postwar period has occurred since $1965 .{ }^{146}$ A person acquiring an asset prior to 1965 may be somewhat annoyed to be informed that he is entitled only to inflation adjustment commencing in 1965 because the Treasury wanted a smaller adjustment table. Nevertheless, when the Treasury is proposing full inclusion of real capital gains in the income tax base, prejudicing this proposal by relatively petty administrative concerns is probably unwise.

138. 2 TREAS. REPORT, supra note 1 , at $\mathbf{1 7 8 - 8 8}$.

139. 1 Treas. RePORT, supra note 1 , at 100-105. The President's Proposals would retain a preferential capital gains rate, although reducing the exclusion from $60 \%$ to $50 \%$. Pres. Proposals, supra note 33, at 164-73. Only individual taxpayers would have the option of indexing capital gains beginning in 1991 in lieu of the preferential tax rate. Id. at 169 .

140. 1 TREAs. Report, supra note 1, at 100-01; 2 TREAs. Report, supra note 1 , at 180.

141. 2 TREAs. REPORT, supra note 1 , at 181 .

142. Id. at 183 .

143. Id.

144. Id

145. Id.

146. I TREAS. REPORT, supra note 1 , at 101 . 
During the three-year transitional period a taxpayer will be entitled to a one-time marked-to-market election ${ }^{147}$ so that he may determine whether current preferential treatment from an unindexed basis is more advantageous than full taxation from an indexed historic basis, limited to post-1964 inflation. ${ }^{148}$ This option, however, would be limited to readily marketable assets. Homeowners would not benefit from the marked-to-market election. Currently, homeowners who are age fifty-five or older are entitled to exclude permanently the first $\$ 125,000$ of nominal gain on the sale of a principal residence. ${ }^{149}$ One of the reasons for the large current exclusion is that much of the gain represents inflation. The Treasury proposes that the first $\$ 125,000$ of real, rather than nominal, gain on such sales be exempted. ${ }^{150}$ Deciding to tax only real capital gains means that the exclusion could have been eliminated or substantially reduced. By not reducing the exclusion, the Treasury proposal would give homeowners who acquired their homes prior to 1965 a rough and very generous offset for limiting the adjustment to post1964 inflation and for not making the marked-to-market election available to them. For persons who acquired their homes since 1965, the exclusion would be a large additional tax preference. Since homeowners would continue to deduct nominal mortgage interest, the additional tax preference for homeowners does not seem warranted.

The proposals to abolish the preferential treatment of capital gains and to introduce indexation mean that the top tax rate on real capital gains would be $35 \%$ as compared with the present $20 \%$ on nominal long-term gains, due to the $60 \%$ exclusion rule and the current top marginal rate of $50 \%$. Whether an individual taxpayer will pay more or less tax will depend on the rate of inflation and the holding period. What is certain is that the proposed system is a better and fairer income tax.

The Treasury proposal would eliminate the current volatility in effective tax rates on capital gains caused by changes in the rate of inflation. The accurate measurement of real losses would mean an associated increase in government risk-sharing that should encourage saving and investment. Taxing real capital gains as ordinary income would eliminate much complexity and uncertainty in the current law. The scope for disputes between taxpayers and the government is greatly restricted by repeal of the preferential treatment of capital gains. For example, tax planning schemes designed to convert ordinary income to capital gains would be deprived of their motivation. Depreciation recapture rules would not be necessary

147. A marked-to-market election permits a taxpayer to recognize a capital gain without the need for a realization. The taxpayer who opts for a marked-to-market election will have a new basis for his capital asset equal to its fair market value at the time of the election.

148. 2 TREAs. RePORT, supra note 1 , at 184.

149. I.R.C. \& 121 (Lawyers Co-op. 1984).

150. 2 Treas. Report, supra note 1 , at 186 . The President's Proposals would also exclude the first $\$ 125,000$ of inflation-adjusted gain from the sale of a principal residence. Pres. Proposals, supra note 33, at 169. 
because there is no need to distinguish between depreciation recapture and a capital gain when both are fully included in income.

One disappointing feature of the proposal, however, is that losses from the sales of investment property would remain subject to the current limitations on capital losses and thus the amount of tax simplification is significantly reduced.151 Losses from sales of investment property-generally all nonpersonal use property not used in a trade or business-would offset gains from such property, with any excess loss deductible up to a maximum of $\$ 3,000$ per year for a noncorporate taxpayer. ${ }^{152}$ Excess investment property losses could be carried forward indefinitely by both individuals and corporations. There is no suggestion that the maximum excess loss of $\$ 3,000$ deductible from other income by noncorporate taxpayers should be indexed. No proposal is made to index excess investment property losses. But because losses of one year are calculated in the dollars of that year, there should be an adjustment when losses are applied against the income of other years. Losses should be deflated by the rate of inflation if carried back and inflated by the rate of inflation if carried forward in order to achieve the correct offset. Perhaps it is not surprising that the Treasury did not deal with this issue, because the timing of gains and losses will still reside with the taxpayer.

Since real capital gains are to be fully included in income, the Treasury, surprisingly, has made no proposal to tax accrued gains at death. Capital gain is a form of income upon which taxation is deferred until there is a realization because of the administrative problem of valuation. Yet assets generally have to be evaluated at death for purposes of administration and for a declining number of estates subject to estate tax. Deeming assets to be disposed of at fair market value at death is a necessary step towards achieving an equitable income tax and would not impose any substantial administrative problem. An estate tax is no substitute for constructive realization at death, and a constructive realization at death is no substitute for an estate tax. At a minimum, the present rule that the basis of all assets adjusts to equal their fair market value at death should be changed. With this change, the next step would be to consider imposing an interest charge for the deferral privilege at the time of realization as a proxy for the taxation of real gains as they accrue. This would permit the elimination of rules limiting the deductibility of losses on the disposition of investment property. A deferral charge at realization would also reduce the "lock in" problem by making persons with substantial unrealized gains less reluctant to change their investment portfolio and incur an immediate tax liability.

2. Depreciation. The Treasury proposes that the basis of depreciable assets be indexed for inflation ${ }^{153}$ and that depreciation allowance should

151. 2 Treas. RePort, supra note 1, at 187. The President's Proposals also retain current capital loss limitation rules. Pres. Proposals, supra note 33, at 172.

152. 2 TREAS. REPORT, supra note 1 , at 182.

153. 1 Treas. RePort, supra note 1, at 105-09. The President's Proposals also index the basis of depreciable assets. Pres. Proposals, supra note 33, at 132-59. 
approximate real economic depreciation. ${ }^{154}$ Under its proposed Real Cost Recovery System (RCRS), all depreciable tangible assets would be assigned to one of seven classes with a fixed depreciation rate ranging from $32 \%$ to $3 \%$ to reflect real economic depreciation. ${ }^{155}$ A taxpayer would prorate the depreciation allowance of a newly acquired asset according to the number of months the asset is placed in service, using a mid-month convention with no inflation adjustment for the first year. ${ }^{156}$ In subsequent years, the remaining unrecovered basis of an asset would be increased annually by the inflation rate prior to determining the depreciation allowance. ${ }^{157}$ To simplify accounting, RCRS would allow a taxpayer to close out the depreciation account for any assets in the year in which only $15 \%$ of the inflation adjusted original basis remains to be depreciated. ${ }^{158}$ The inflation adjusted basis of an asset would be used to compute gain or loss on the disposition or retirement of an asset, and the gain or loss would be fully included or deducted from income. ${ }^{159}$

The current system is regarded by the Treasury as one that is deeply flawed. ${ }^{160}$ The investment tax credit and the accelerated cost recovery system (ACRS) were introduced to combat the inflationary erosion of the value of depreciation allowances. ${ }^{161}$ However, with the proposed inflation indexing of the remaining unrecovered basis of an asset, future depreciation allowances will maintain their real value. The Treasury has therefore proposed that investment tax credit and accelerated depreciation be eliminated. ${ }^{162}$ The Treasury believes the proposal possesses a number of significant advantages. ${ }^{163}$ Greater economic neutrality will improve the allocation of resources. Effective tax rates on depreciable property will no longer vary according to the asset life, and effective tax rates will no longer vary across industries. The system will no longer favor investment in depreciable assets over investment in labor and inventories. Business planning will be more certain because the value of future depreciation allowances will be

154. 2 Treas. Report, supra note 1, at 152-72. The President's Proposals are in accord with the Treasury's suggestion that depreciation should approximate real economic depreciation. Pres. Proposals, supra note 33 , at 134.

155. 2 Treas. RePort, supra note 1, at 158. The President proposes a Capital Cost Recovery System (CCRS) that would assign depreciable assets to one of six classes, with depreciation rates ranging from 55\% to 4\%. Pres. Proposals, supra note 33, at 138 .

156. 2 Treas. Report, supra note 1, at 159. The President's Proposals are identical. Pres. Proposals, supra note 33, at 138.

157. 2 TrEas. REPORT, supra note 1 , at 158. The President's Proposals adopt the same system. Pres. Proposals, supra note 33, at 139.

158. 2 Treas. Report, supra note 1 , at 158 . The President's Proposals have no $15 \%$ close-out provision. In fact, CCRS introduces an additional complexity by switching from a declining-balance rate to a straight-line depreciation method when the straight-line method yields a greater allowance than the declining-balance method (assuming a half-year convention). Pres. Proposals, supra note 33, at 138.

159. 2 Treas. Report, supra note 1, at 158-59. The President's Proposals are identical. Pres. Proposals, supra note 33, at 142.

160. 1 Treas. RePORT, supra note 1, at 105-06; 2 TREAS. RePORT, supra note 1, at 154-55.

161. 1 TREAS. REPORT, supra note 1 , at 105.

162. Id. at 106. The President's Proposals would also repeal the investment tax credit. Pres. Proposals, supra note 33, at 160-63.

163. I TREAS. Report, supra note 1, at 106-09; 2 Treas. RePORT, supra note 1, at 162-63. 
automatically corrected for inflation. The current investment tax credit and accelerated depreciation are front-loaded and are of little value to new firms or firms in ailing industries neither of which can fully utilize their benefits. However, the lowering of the corporate rate from $46 \%$ to $33 \%$ made possible by the broadened base will assist all corporations and enhance competition. The elimination of front-loading of tax benefits will reduce the advantages of tax shelters and misallocation of resources which is inherent in them.

3. Inventory. The Treasury has proposed that taxpayers be permitted to use an indexed first in, first out (FIFO) method of inventory tax accounting for taxation years beginning on or after January $1,1986 .{ }^{164}$ The Treasury states that two-thirds of inventories in the United States are owned by firms which use FIFO tax accounting. ${ }^{165}$ Under FIFO, ending inventories are valued at most recent purchases or production costs; therefore, during inflation, cost of goods sold or used is understated and profit is overstated. Under the last in, first out (LIFO) accounting method, ending inventory is valued at the oldest purchase or production cost; therefore, in times of rising prices the cost of goods sold or used is higher than under FIFO. LIFO thus copes with inflation better than FIFO, but it takes into account only price changes in specific inventoried goods that may not reflect general price trends, and it results only in the deferral rather than the elimination of inflationary gains. Under indexed FIFO, the percentage increase in the Consumer Price Index would be applied to the number of units in the beginning inventory that does not exceed the number of units in the ending inventory. ${ }^{166}$

Since 1939, taxpayers who use the LIFO method for tax accounting purposes have been required to use it in preparing their financial statements for shareholders and for credit purposes. The Treasury proposal would repeal the conformity requirement, and the requirement for IRS consent to change to LIFO or to indexed FIFO would be waived during a transition period. ${ }^{167}$

4. Debt. Since nominal interest rates include an inflation premium to compensate the lender for the loss in real value of the principal, interest income and expense are overstated by current tax law, which makes nominal interest receipts fully taxable and nominal payments fully deductible. ${ }^{168}$ The Treasury notes that perfect adjustment for inflation would require an annual deduction by a creditor for each outstanding loan equal to the product of the

164. I Treas. Report, supra note 1, at 109-11; 2 Treas. Report, supra note 1, at 189-92. The President's Proposals are in accord with the Treasury Report. Pres. Proposals, supra note 33, at 174-78.

165. 2 Treas. Report, supra note 1, at 191. But see 1 Treas. RePORT, supra note 1, at 111 (where the figure is $95 \%$ ).

166. 2 Treas. Report, supra note 1, at 190. The President's Proposals are identical. Pres. Proposals, supra note 33, at 175-76.

167. 2 Treas. Report, supra note 1, at 191. The President proposes the same repeal and waiver.

Pres. Proposals, supra note 33, at 176.

168. 1 Treas. Report, supra note 1, at 111; 2 Treas. REPORT, supra note 1, at 193-94. 
inflation rate and the loan principal to recognize the real loss, and a corresponding inclusion in income by the debtor to recognize the real gain. ${ }^{169}$ If, for example, $A$ loans $\$ 1,000$ to $B$ at a nominal rate of interest of $10 \%$ when the inflation rate is $4 \% A$ should be entitled to deduct $\$ 40$ (inflation rate of $4 \%$ times the loan principal of $\$ 1,000$ ) which is the real loss in the value of the principal. $B$ 's liability to repay the principal would correspondingly be reduced in real terms and he should add $\$ 40$ to his income. The result is that $A$ would include a net amount of $\$ 60$ in income and $B$ would deduct a net amount of $\$ 60$ from income. The equivalent result could be obtained by a fractional interest exclusion equal to the rate of inflation divided by the nominal rate of interest $(4 \% / 10 \%)$. $A$ would exclude $40 \%$ of the interest payment of $\$ 100$ from his income, and $B$ 's interest expense would also be reduced by $\$ 40$.

According to the Treasury, an inflation adjustment for each outstanding loan would be extremely complicated. The Report proposes a surrogate based on the fractional exclusion technique. ${ }^{170}$ The taxpayer would first determine his net interest income (excluding tax-exempt interest) or expense (excluding mortgage interest on the principal residence plus $\$ 5,000$ of additional interest paid). This net interest income or expense would then be multiplied by a fractional exclusion rate equal to the rate of inflation divided by the sum of the rate of inflation and an assumed constant $6 \%$ real rate of return. ${ }^{171}$ The net interest income, reduced by the fractional exclusion rate, would be included in income. The net interest expense, reduced by the fractional exclusion rate and subject to the interest deduction limitation, would be deducted from income.

The Treasury concedes that one fractional exclusion rate for all borrowers and lenders for each rate of inflation would only provide a rough adjustment for inflation but rightly concludes that such adjustment "will clearly be more appropriate than the zero inflation assumption implicit in the current law's treatment of all nominal interest as taxable income or deductible expense."172 The fractional exclusion proposal would reduce the amount of tax arbitrage. Many tax avoidance schemes are based on using borrowed funds to acquire tax-preferred assets. The fractional exclusion of interest will have the beneficial effect of reducing the attractiveness of such opportunities. Moreover, if capital gains are to be indexed, an inflation adjustment for

169. 1 Treas. REPORT, supra note 1 , at 114.

170. Id. at 111-16; 2 Treas. Report, supra note 1, at 193-200. The President's Proposals would expand interest subject to the current investment interest limitation to include: (1) interest not incurred in connection with business (except for interest on a mortgage of the taxpayer's principal residence if the debt does not exceed the fair market value of the residence); (2) the taxpayer's share of interest expense of $S$ corporations (except for $S$ corporations in which the taxpayer is an active participant in management); and (3) the taxpayer's distributive share of interest expense of limited partnerships of which the taxpayer is a limited partner. Interest subject to the limitation could be deducted to the extent of the sum of $\$ 5,000$ ( $\$ 2,500$ if the taxpayer is married but filing a separate return) and the taxpayer's net investment income. Pres. Proposals, supra note 33, at 323.

171. This estimate of the real rate of interest appears high. Historically the real rate of interest has generally remained within the range of $1.5 \%$ to $3.5 \%$.

172. 1 Treas. Report, supra note 1 , at 114 . 
interest is imperative. Otherwise, in a period of inflation, there would be a strong incentive for investors in high tax brackets to borrow, obtaining the tax advantage of debt while investing in capital assets whose indexation shields them from the impact of inflation. This "clientele effect"178 is aggravated by inflation and the fractional exclusion would have a moderating impact. 174

The approaches to interest deductibility in Canadian and in American law are significantly different. The Canadian position is that only interest on borrowed money used to earn income from a business or property may be deducted. ${ }^{175}$ The general rule in the United States is that all interest is deductible, ${ }^{176}$ except that no deduction is allowed to purchase or carry obligations which generate tax-exempt income. ${ }^{177}$ There is also a limitation on the deductibility of investment interest, ${ }^{178}$ but consumer interest-that is, interest incurred to acquire personal assets-is deductible without limitation in the United States, while in Canada none is deductible. The Treasury proposal would, by expanding the current investment interest limitation, reduce the difference between the two systems. Only mortgage interest on the taxpayer's principal residence would continue to be deductible without limit, provided that the debt did not exceed the fair market value. ${ }^{179}$ All other interest not incurred in connection with a trade or business would be subject to the investment interest limitation and would be deductible only to the extent of the taxpayer's net investment income plus $\$ 5,000 .{ }^{180}$ Any interest deduction disallowed would be treated as investment interest expense of the following year. This provision would represent a substantial tightening of the investment interest limitation.

Mortgage interest on the taxpayer's principal residence and on the first $\$ 5,000$ of any additional interest expense would be unaffected by the proposal. Except for the first $\$ 5,000$ of net interest expense, mortgage interest on the taxpayer's principal residence would receive preferential treatment over all other interest expense. The fractional exclusion rate would not be applied to mortgage interest or to the first $\$ 5,000$ of net interest expense. ${ }^{181}$ This increases the relative attractiveness of mortgage debt compared with other debt, and higher inflation would make it even more

173. The "clientele effect" is the tendency under a progressive income tax for higher taxbracket taxpayers to be net borrowers, because the greater tax saving from the interest deduction exceeds the increased tax liability of lower bracket taxpayers who therefore tend to be net creditors. 2 TREAS. REPORT, supra note 1 , at 194.

174. Id.

175. Income Tax Act, ch. 63, \& 201(1)(c), 1970-1972 Can. Stat 1311, 1370.

176. I.R.C. \& 163(a) (Lawyers Co-op. 1974).

177. Id. \& 265(2).

178. Id. \& $163(\mathrm{~d})$.

179. I TREAs. Report, supra note 1, at 141; 2 TrEas. Report, supra note 1, at 194-95. The President's Proposals are in accord with the Treasury Report. Pres. Proposals, supra note 33, at 323.

180. I TREAs. RePORT, supra note 1, at 140-41; 2 TREAs. RePORT, supra note 1, at 331-33. Cf. Pres. Proposals, supra note 33, at 323 (the Proposals expand interest subject to current investment interest limitations to include three more types of interest).

181. 2 Treas. Report, supra note 1, at 194-95. 
attractive. If the present mortgage interest deduction has caused a substantial over-investment in housing, the proposed changes should reinforce this tendency.

The Carter Commission rejected the idea of making mortgage interest payments deductible and criticized the mortgage interest deduction because it discriminated against the renter. ${ }^{182}$ However, it failed to recognize that in denying the deductibility of mortgage interest, the Canadian tax system discriminates against the homeowner with a large mortgage and in favor of the homeowner with clear title. A tax system that discriminates against the $35 \%$ of households living in rental accommodations is undesirable; but a tax system that fails to discriminate among the $65 \%$ of households in owneroccupied dwellings whose equity ranges from almost zero to $100 \%$ is equally undesirable. The only really satisfying solution is to include in income the imputed rental value of owner-occupied dwellings and to permit mortgage interest and related expenses to be deducted. This system would be fair between renters and homeowners, and between homeowners with varying amounts of equity in their homes. Eventually, the imputed rental value of owner-occupied homes will have to be included in the income tax base in both the United States and Canada. The desirability of this inclusion has long been recognized. In 1864, the U.S. Commissioner of Internal Revenue said that "he was unable to see. . . why one who lives in his own house should not be taxed on its rental value, as much as if he let it to another and put the rent in his purse."183 Additionally, no ideal treatment of interest in the income tax system can exist without the imputation of the rental value of owner-occupied homes.

\section{The Dividend-Paid Deduction for Corporations}

The Treasury proposes permitting corporations a deduction of $50 \%$ of dividends paid out of profits that have borne the full corporate tax. ${ }^{184}$ The Carter Commission proposed full integration of corporate and individual income tax for resident Canadian shareholders. ${ }^{185}$ The corporation tax, according to the Carter Report, was to become simply a withholding tax that was to be fully attributed to resident Canadian shareholders through a grossup and credit system for dividends and an attribution system for retained earnings. ${ }^{186}$ Liquidity problems would be avoided by having a top marginal tax rate for individuals pegged to the corporate rate of $50 \% .{ }^{187}$

182. 3 CARTER REPORT, supra note 8, at 49. I have indicated that the Canadian approach to the deductibility of interest is flawed in The Interest Deduction Dilemma, 21 Canadian TAX J. 817 (1973).

183. Report of the Commissioner of InTERnAl Revenue 13 (1864), quoted in Hellenbrand, Itemized Deductions for Personal Expenses and Standard Deductions in the Income Tax Law, 1 TAx Revision COMPENDIUM, supra note 43 , at $375,376$.

184. I TREAS. Report, supra note 1, at 118-19; 2 TREAs. RePORT, supra note 1, at 134-44. The President's Proposals would only permit a deduction of $10 \%$ of dividends paid. Pres. Proposals, supra note 33, at 122.

185. 4 CARTER RePORT, supra note 8 , at 83 .

186. Id. at 83-93.

187. Id. at 83 . 
The argument that a fair and efficient income tax system necessitates full integration of individual and corporate tax has gained many adherents. However, there is doubt about the wisdom of providing relief that is restricted to distributed corporate income. The Treasury summarily dismisses the adoption of full integration, citing technical difficulties. ${ }^{188}$ The revenue loss from full integration also might well have been an important factor because, after acknowledging the advantage of full relief from double taxation of dividends, the Treasury says its proposal for half deduction "is based primarily on considerations of revenue loss." 189

The Treasury indicates that the 50\% dividend-paid deduction would reduce the differential treatment of equity and debt capital and thus make equity securities more competitive with debt. ${ }^{190}$ This may reduce corporate reliance upon debt capital and decrease the vulnerability of corporations to risks of bankruptcy caused by cyclical changes in the economy. The Treasury also indicates that corporations with shareholders in high tax brackets are encouraged to retain earnings in order to defer income tax at the shareholder level. ${ }^{191}$ The dividend relief from reducing the corporate tax on distributed earnings by $50 \%$ would provide an incentive to pay larger dividends. The Treasury believes that this would result in efficiency gains for the economy. ${ }^{192}$ The corporations that pay larger dividends and seek new funds will, to a greater extent, be subjected to "the discipline of the marketplace and less likely to make relatively unproductive investments simply because they have available funds." 193 Another efficiency gain foreseen is that the larger dividend distribution would swell the pool of funds available to new firms with relatively higher productivity opportunities than the older dividend-paying corporations.

The proposed full taxation of real capital gains may also have an impact on corporate dividend policy by reducing the advantages of retaining profit within the corporation. The Treasury believes that "double taxation of corporate earnings distributed to shareholders also increases the cost of capital for corporations and discourages capital-intensive means of production in the corporate sector.'194 By reducing the general corporate rate from $46 \%$ to $33 \%$, and providing a $50 \%$ dividend-paid deduction, there should be efficiency gains from the better allocation of capital.

188. 1 TREAS. RePORT, supra note 1 , at 118 .

189. Id. at 119 .

190. Id.; 2 Treas. Report, supra note 1, at 141. The President's Proposals reach the same conclusion on the basis of the 10\% deduction. Pres. Proposals, supra note 33, at 126.

191. 2 Treas. Report, supra note 1 , at 135. The President's Proposals recognize the same tendency. Pres. Proposals, supra note 33, at 121.

192. 2 Treas. Report, supra note 1 , at 141 . The President's Proposals similarly predict efficiency gains. Pres. Proposals, supra note 33, at 126.

193. 1 TREAS. REPORT, supra note 1 , at 19.

194. 2 TreAs. RePORT, supra note 1 , at 195. 
Having decided that there should be partial relief for dividends, the Treasury rejects the imputation approach adopted by many countries. ${ }^{195}$ Under an imputation approach, part of the corporation's pre-tax profit and part of the corporation tax paid is attributed to the shareholder. The shareholder thus includes in his income the dividend plus a grossed-up amount to reflect part of the pre-tax profit and receives a credit for part of the corporation tax paid. The rejection of such an approach is of interest to Canada because this is the method that we have adopted. However, the rejection is done in an exceedingly cursory way; the Treasury Report simply states that "in the context of the United States economy and tax system, an imputation approach to dividend relief would be extremely cumbersome." 196 As the Canadian economy and tax system is similar to the American, greater elaboration on this point would have been preferable.

The Treasury recognizes that the imputation system would permit dividend relief to be accorded only to American shareholders and that no tax treaty problem would arise. ${ }^{197}$ The Treasury's proposal to allow domestic corporations a deduction equal to one-half of dividends paid out of fully taxed earnings would make the relief available to both domestic and foreign shareholders. To prevent the benefit of the dividend-paid deduction from accruing to foreign shareholders, the Treasury proposes to levy a compensatory withholding tax of $16.5 \%$ (50\% of the proposed corporate income tax rate of $33 \%$ in addition to the current withholding tax. 198 However, to impose a compensatory withholding tax on dividends paid to residents of treaty countries, thereby negating the dividend relief accorded to the company paying the dividend, would constitute a treaty violation because most treaties establish a maximum rate of withholding tax on dividends. There is an exact economic equivalence between limiting a credit for corporate taxes paid under an imputation system to resident shareholders and imposing a compensatory withholding tax on distributions to foreign shareholders under a dividend-paid deduction system. But the latter results in a violation of tax treaties while the former does not. The Treasury, although it would regard such a violation as only a technical violation, states that it would not initially impose a compensatory withholding tax on dividends paid to residents in treaty countries. ${ }^{199}$ It does indicate, however, that treaty negotiations will be undertaken with countries possessing imputation systems that have previously not extended the benefits of dividend

195. Id. at 142-43. The President's Proposals also reject an imputation system. Pres. Proposals, supra note 33, at 127.

196. 2 TREAS. REPORT, supra note 1 , at 143.

197. Id. at 142. The President's Proposals implicitly recognize that an American imputation system would not violate tax treaties. Pres. Proposals, supra note 33, at 128.

198. 2 Treas. Report, supra note 1, at 139-40. The President's Proposals would also impose a compensatory withholding tax of $3.3 \%$ (10\% of the proposed corporate income tax rate of $33 \%)$. Pres. Proposals, supra note 33, at 125.

199. 2 TREAS. REPORT, supra note 1, at 143. Residents of treaty countries would be immune from the compensatory withholding tax under the President's Proposals as well. Pres. Proposals, supra note 33 , at 126 . 
relief to United States residents in order to reverse that position. ${ }^{200}$ The Treasury also indicates that "[u]nwillingness of treaty partners to negotiate meaningfully on this issue would cause a reevaluation of the decision unilaterally to extend benefits to foreign shareholders in treaty countries."201 When the only reason given for opting for the dividend-paid deduction is that the imputation system is in some undefined way cumbersome, a major motive may really be to reopen the treaty issue of dividend relief for United States residents.

The United States, with far more direct investment in Canada than Canada has in the United States, would obviously benefit were Canada to accord dividend relief to United States residents. However, as the Treasury Report indicates, many countries have adopted partial relief of the double taxation of dividends "for policy reasons that do not apply equally to the United States." 202 In 1949, Canada first adopted a dividend tax credit which was available only to individuals residing in Canada. ${ }^{203}$ The dividend tax credit was both an attempt to reduce the burden of double taxation of dividends and an incentive for Canadians to purchase equity stocks of Canadian corporations. The dividend tax credit of $20 \%$ of dividends received from Canadian corporations reduced the tax burden of all shareholders by an equal amount per share held. The dividend tax credit is a more equitable way of providing partial relief than the dividend exclusion method. With dividend exclusion the value of the exclusion depends on the marginal tax rate of the shareholder, and the relief is thus accorded in a regressive way. (It is not surprising that the Treasury has advocated the elimination of the $\$ 100$ dividend exclusion. ${ }^{204}$ ) Canada's current imputation system is more equitable than a dividend-received tax credit because the excessive taxation is reduced by the same percentage for all resident taxpayers. Since Canada's imputation system, a gross-up and credit system, is simply a successor to the dividend tax credit first implemented in 1949, and since a substantial amount of American investment in Canada has occurred since preferential treatment was first accorded to Canadian resident shareholders, Canada may validly and reasonably decline to make the benefit of dividend relief available to nonresident taxpayers.

The Treasury Report makes the point that reducing the corporate tax rate from $46 \%$ to $33 \%$ and reducing the maximum individual rate from $50 \%$ to $35 \%$ would reduce the excessive taxation only by a small amount, from $23 \%$ to $21.45 \%$ for shareholders in the top marginal rate bracket. This can be seen in Table 1 by comparing the last lines of columns (4) and (9). The table also

200. 2 Treas. Report, supra note 1, at 143. The President's Proposals also suggest reviewed treaty negotiations. Pres. Proposals, supra note 33, at 129.

201. 2 TreAs. REPORT, supra note 1 , at 143.

202. Id. at 141 .

203. Act of Dec. 10, 1949, Ch. 25, \& 17, 1949 Can. Stat. 165, 180.

204. 1 Treas. Report, supra note 1 , at 119 ; 2 Treas. RePort, supra note 1 , at 145 . The President's Proposals would also repeal the $\$ 100$ dividend exclusion. Pres. Proposals, supra note 33, at 130. 


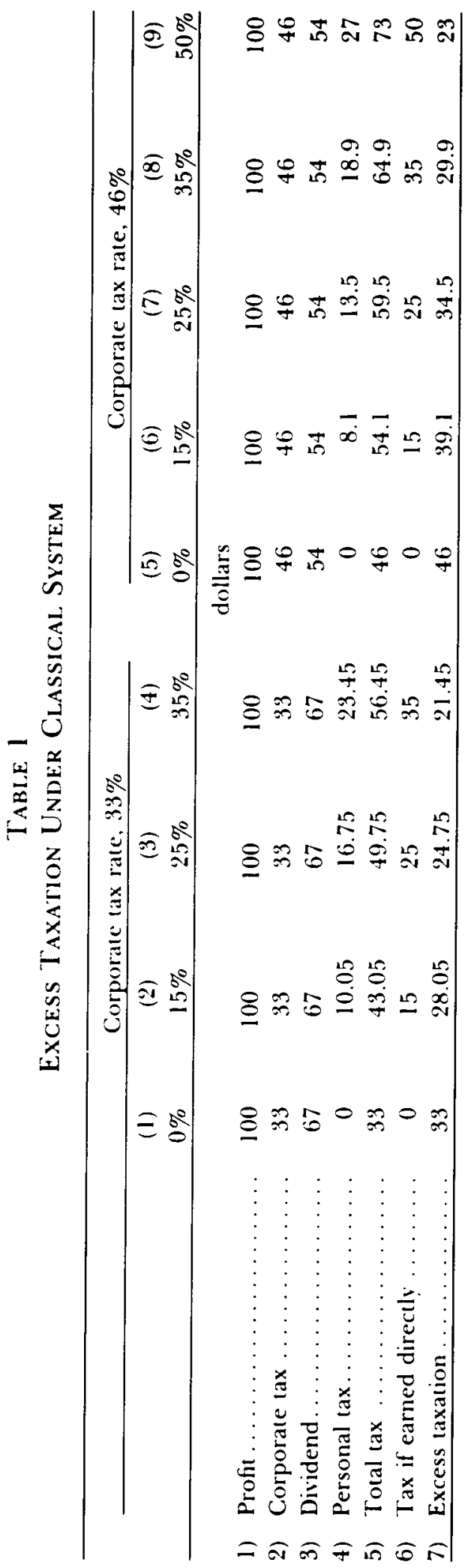


indicates that the problem of the classical system, taxing the corporation and then taxing the shareholder, is basically one of excessive taxation and not one of double taxation because the greatest excessive taxation occurs when the marginal tax rate of the shareholder is zero and thus only one level of $\operatorname{tax}$ is paid.

The Treasury Report contends that its corporate level deduction of 50\% of fully taxed corporate earnings paid out as dividends will reduce the percentage of double taxation by $50 \% .205$ A corporation would be required to maintain a "Qualified Dividend Account"; each year the amount of taxable income bearing the full corporate rate would be added to this account, and dividends paid by the corporation for which there was a dividend-paid deduction would be subtracted but the balance could never be reduced below zero. ${ }^{206}$ This description of the Qualified Dividend Account does not appear to have the effect of reducing the excessive taxation by $50 \%$. If a corporation earns $\$ 100$ and pays tax of $\$ 33$, its Qualified Dividend Account would be increased by $\$ 100$. However, if it must declare a dividend of $\$ 100$, half of which is deductible in calculating its taxable income (in order to obtain a rebate of $\$ 16.50$ ), the percentage of double taxation being relieved is less than $50 \%$. For $50 \%$ to be relieved, for every dollar of dividends, 100/83.5 must be deducted from the Qualified Dividend Account, and $50 \%$ of that same amount must be deducted in calculating the corporation's taxable income in order to obtain the appropriate rebate. Thus, if a corporation earned $\$ 100$, paid corporate tax of $\$ 33$, and declared the maximum dividend, it would not declare a dividend of $\$ 67$ but would anticipate that half of the corporate tax would be returned to it and declare a dividend of $\$ 83.50$ ( $\$ 67$ $+\$ 16.50$ ). The Qualified Dividend Account would be increased by the $\$ 100$ of profit on which the full corporate rate was paid and should be diminished by $100 / 83.5 \times 83.50$ or $\$ 100$, by the dividend. The Qualified Dividend Account would return to zero. The corporation would be entitled to a deduction of $50 \%$ of $100 / 83.5 \times 83.50$ or $\$ 50$, and at a tax rate of $33 \%$ this will trigger a refund of $\$ 16.50$.

Table 2 indicates that the overtaxation of dividend income would be reduced by $50 \%$. The Treasury states that the proposal for partial dividend relief means that "the maximum overall tax rate on corporate earnings distributed as dividends to individual shareholders would be approximately $45 \%$."207 As shown in column (4) of Table 2, the total tax on corporate dividends for a person at the top marginal rate of $35 \%$ would be $45.73 \%$ and is thus consistent with the Report.

The Treasury Report contends that the dividend-paid deduction should be limited to ensure that it is only permitted on dividends attributable to

205. 2 TREAS. REPORT, supra note 1 , at 141.

206. Id. at 136. The President proposes an identical scheme. Pres. Proposals, supra note 33, at $122-23$.

207. 2 Treas. RePORT, supra note 1 , at 141. 
TABLE 2

Reduction in Excess Taxation Through the Dividend-Paid DEDUCTION

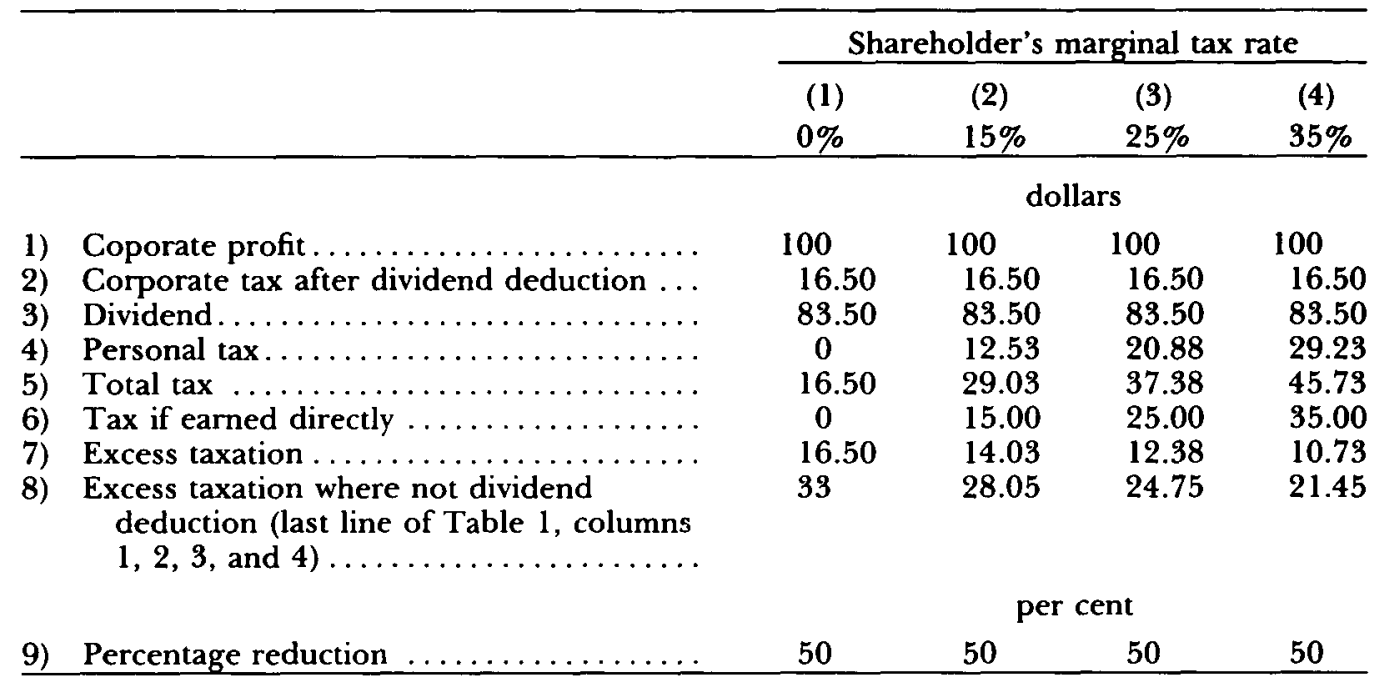

corporate earnings that have borne the regular corporate income tax. ${ }^{208}$ The Qualified Dividend Account is proposed to carry out this purpose, and the account would not include any of the corporation's tax preference income. However, "dividends will be presumed to be paid first from fully taxed income." 209 The order in which tax preference income is assumed to be paid out is exceedingly important; by stacking the preference income last, the most favorable corporate allocative rule is adopted and thus some tax preferences will be passed through to the shareholder. A more reasonable allocative rule for a corporation that has some income that is fully taxed and other income that enjoys tax preferences would be a proration of the dividend on the basis of fully taxed income and preference income. If most tax preferences are eliminated, stacking the preference income last may not be a serious defect.

The Canadian imputation or gross-up and credit system does not depend upon whether the corporation paid any tax at all upon the income that is being distributed as a dividend. As long as the dividend is paid by a taxable Canadian corporation, the individual resident Canadian shareholder takes as income the dividend plus $50 \%{ }^{210}$ and is entitled to a credit that is equivalent to $50 \%$ of the dividend. ${ }^{211}$ If the corporation in fact paid $331 / 3 \%$ tax and distributed all its after-tax income, there would be full integration. The

208. Id. at 136 .

209. 1 Treas. Report, supra note 1, at 119. The President's Proposals are in accord with the limitation of this deduction. Pres. Proposals, supra note 33, at 122.

210. Income Tax Act, ch. 1, \$ 36(1), part I, 1977-1978 Can. Stat. 1, 58 (amending paragraph 82(1)(b) of the Income Tax Act).

211. Income Tax Act (No. 2), ch. 140, part I, \& 81(1), 1980-1983 Can. Stat. 3777, 3961 (amending section 121 of the Income Tax Act). Section 121 now provides for a dividend tax credit 
standard corporate rate is $46 \%$ but some corporations, particularly in the extractive industries, pay no corporation tax. Nevertheless, their resident Canadian shareholders are still entitled to a credit equivalent to $50 \%$ of the dividend paid. Treating tax preferences as equivalent to taxes paid is inconsistent with the integration concept which was evolved by the Carter Commission.

Charles E. McClure has stated: "Canada's rejection of full integration in favor of a form of dividend relief that allows tax preferences to benefit shareholders in a rather haphazard and inequitable way is usually viewed with disappointment by public finance experts." 212 However, he does acknowledge that Canada's imputation system represents "a substantial step forward from the earlier system that allowed a twenty percent credit for dividends received, but without gross-up."213

What is feasible tax reform depends on what has been done previously. Because Canada had a $20 \%$ dividend tax credit granted to shareholders regardless of whether any tax had been paid by taxable Canadian corporations, there were strong vested interests intent on ensuring that the gross-up and credit system would also not depend on corporate taxes actually paid. The United States, with its strong adherence to the classical system, is in a position to take a firm stand on granting relief for dividend income. The stacking of preference income last in determining the availability of the dividend paid deduction does not constitute a firm stand. Canada is notably one of the few countries using the imputation system which provides gross-up and credit without regard to the actual payment of corporate tax. French, British, and West German systems "have quite detailed provisions intended to prevent relief from corporate income tax not actually paid."214 The proposed American dividend-paid deduction could provide relief for corporate tax which has not been paid.

The dividend-paid deduction for the corporation and the gross-up and credit system for the individual shareholder can be equivalent because they both reduce the excessive tax burden on corporate dividends by the same percentage no matter what the marginal tax rate of the shareholders may be. ${ }^{215}$ However, they can be very different in the scope of their coverage. The Treasury proposes that the dividend-paid deduction be available for dividends paid to U.S. tax-exempt organizations. ${ }^{216}$ The Carter Commission also proposed that tax-exempt Canadian entities should benefit from full integration. ${ }^{217}$ However, the gross-up and credit system in Canada has not

of $68 \%$ of the gross-up but, after taking into account the provincial tax, this is equivalent to a credit of $100.64 \%$ of the gross-up in provinces levying tax at $48 \%$ of the federal tax payable.

212. C. MCLure, JR., Must Corporate Income Be TaXed Twice? 71 (1979).

213. Id. at 71-72.

214. Id. at 69.

215. R. Boadway \& H. Kitchen, Canadian Tax Policy 207-09 (2d ed. 1984).

216. 1 Treas. Report, supra note 1 , at 119. The President's Proposals are silent on the issue of the availability of the deduction for dividends paid to tax-exempt organizations.

217. 4 Carter Report, supta note 8, at 31 . 
been made available to, for instance, Registered Pension Plans. To the extent that partial dividend relief has encouraged absolute increases in dividends and has caused corporate shares to increase in value, Registered Pension Plans have benefited. However, such plans have been denied the direct benefit of the gross-up and credit. As lower-income Canadians in general participate indirectly in the stock market through such vehicles as Registered Pension Plans, denial of the benefit of gross-up and credit to such tax-exempt entities appears inequitable. The Treasury proposal appears fairer in this regard, because U.S. tax-exempt organizations are to have the benefit of dividend relief, even though the Treasury does say that such relief will be subject to continuing review. ${ }^{218}$

It may now be time to reconsider the dividend tax credit in Canada. The Minister of Finance, Michael Wilson, has noted that "the effect of the tax incentives has been to reduce the average federal corporate income tax rate from thirty-six percent of financial statement profits to fifteen percent."219 These incentives also reduce provincial corporate tax revenue and cause the total effective corporate tax rate to be about $20 \%$ with tax on the small business corporation being substantially lower. However, the gross-up and credit system will produce full integration for distributed earnings provided that the corporation pays tax at $331 / 3 \%$. The system thus on average gives credit for a large amount of corporate tax that is not paid and therefore produces superintegration for distributed earnings.

In 1985, a married taxpayer under sixty-five years of age whose only source of income is dividends from taxable Canadian corporations will be able to receive up to $\$ 51,206$ in dividends without paying any federal or provincial income tax. ${ }^{220}$ This is a substantial amount of income to be exempt from personal income taxation, and when one considers the size of the investment

218. I TREAS. REPORT, supra note 1 , at 119.

219. Canada, Dep't of Finance, A New Direction for Canada 39 (1984).

220. This amount assumes that the individual is entitled to the basic personal exemption of $\$ 4,140$, the married exemption of $\$ 3,630$, the $\$ 1,000$ investment income deduction and receives only dividend income:

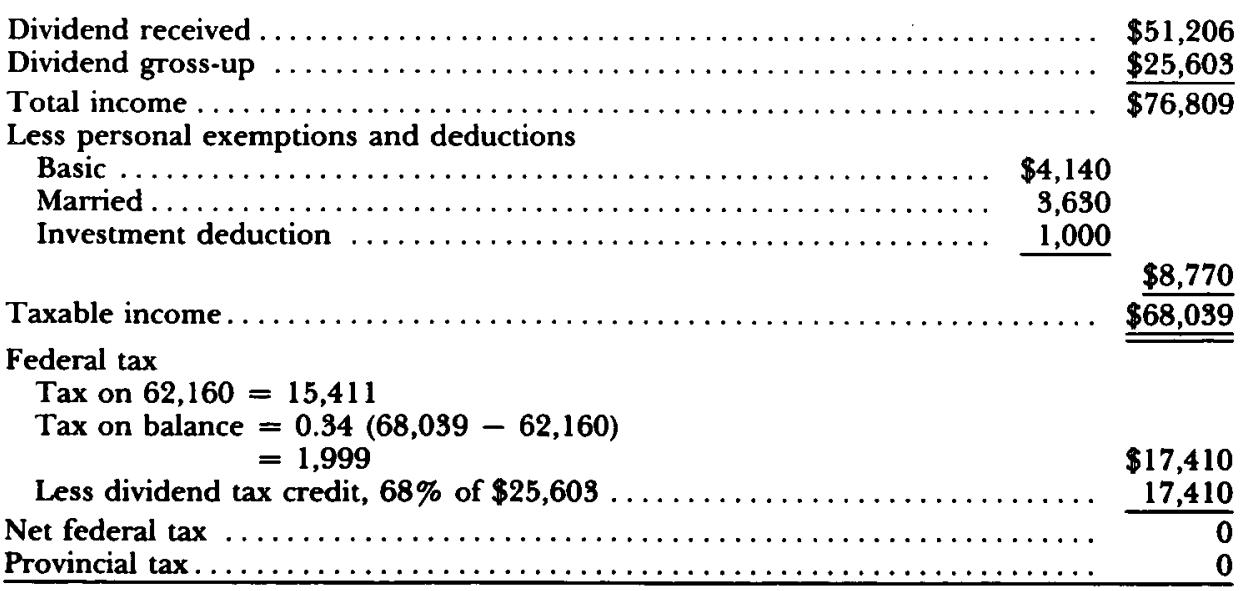


portfolio which is necessary to produce such an amount, the preferential treatment accorded to dividends is clearly indicated. On January 18, 1985, the Toronto Stock Exchange 300 Composite had a dividend yield of 3.7\%;221 thus, a taxpayer who had dividend income of $\$ 51,206$ could have a portfolio with a fair market value of $\$ 1,383,946$ and pay no personal income tax. ${ }^{222}$

The justification for this preferential treatment is that the corporation has prepaid the personal income tax by paying the corporate tax. However, there are many taxable Canadian corporations that pay no corporate income tax; moreover, the effective average federal corporate income tax has been reduced to $15 \% .{ }^{223}$ Reconsidering the gross-up and credit system or increasing the effective tax rates on corporations seems warranted.

Throughout the period since 1950, the corporate income tax revenue has been declining as a percentage of total income tax revenue in both Canada and the United States. This dramatic change is clearly shown in Table 3. The Treasury's proposals, although revenue neutral, would increase the amount of tax on corporations and diminish the tax on individuals relative to the tax revenue which would be raised under current tax law. The Treasury has estimated total income tax revenue for the period 1986 to 1990 inclusive under current law to be $\$ 2,805.4$ billion, of which $\$ 541.8$ billion or $19.3 \%$ would be corporate income tax revenue. ${ }^{224}$ Under the proposals the total income tax revenue is estimated to be $\$ 2,823$.0 billion for the same five-year period, of which $\$ 706.9$ billion or $25 \%$ would represent corporate income tax revenue. ${ }^{225}$ The Treasury proposals would reverse the trend indicated in Table 3. Corporate income tax revenue would no longer continue to represent a declining proportion of total income tax revenue. This change in policy is warranted in Canada as well as in the United States to promote a more neutral tax system which will result in a better allocation of resources. It is perhaps more urgently required in Canada to justify its very generous gross-up and credit for dividends.

\section{IV}

\section{Conclusion}

The Treasury Report represents a comprehensive and balanced set of proposals for fundamental tax reform. Its most significant contribution lies in the adoption of a comprehensive approach to full indexation of capital income. This is important because, without a satisfactory measurement of

221. Financial Post, January 26, 1985, at 14.

222. This is determined as follows:

$$
\frac{\$ 51.206 \times 100}{3.7}=\$ 1,383,946
$$

If the individual had $\$ 51,206$ in dividend income from preferred shares, however, the market value of his portfolio would be $\$ 599,602$ on the basis that the average stock yield on January 18,1985 for 18 preferred shares was $8.54 \%$.

$$
\frac{\$ 51.206 \times 100}{8.54}=\$ 599,602
$$

229. Canada, Dep't of Finance, a new Direction for Canada 39 (1984).

224. I TREAs. Report, supta note 1 , at 45.

225. Id. 


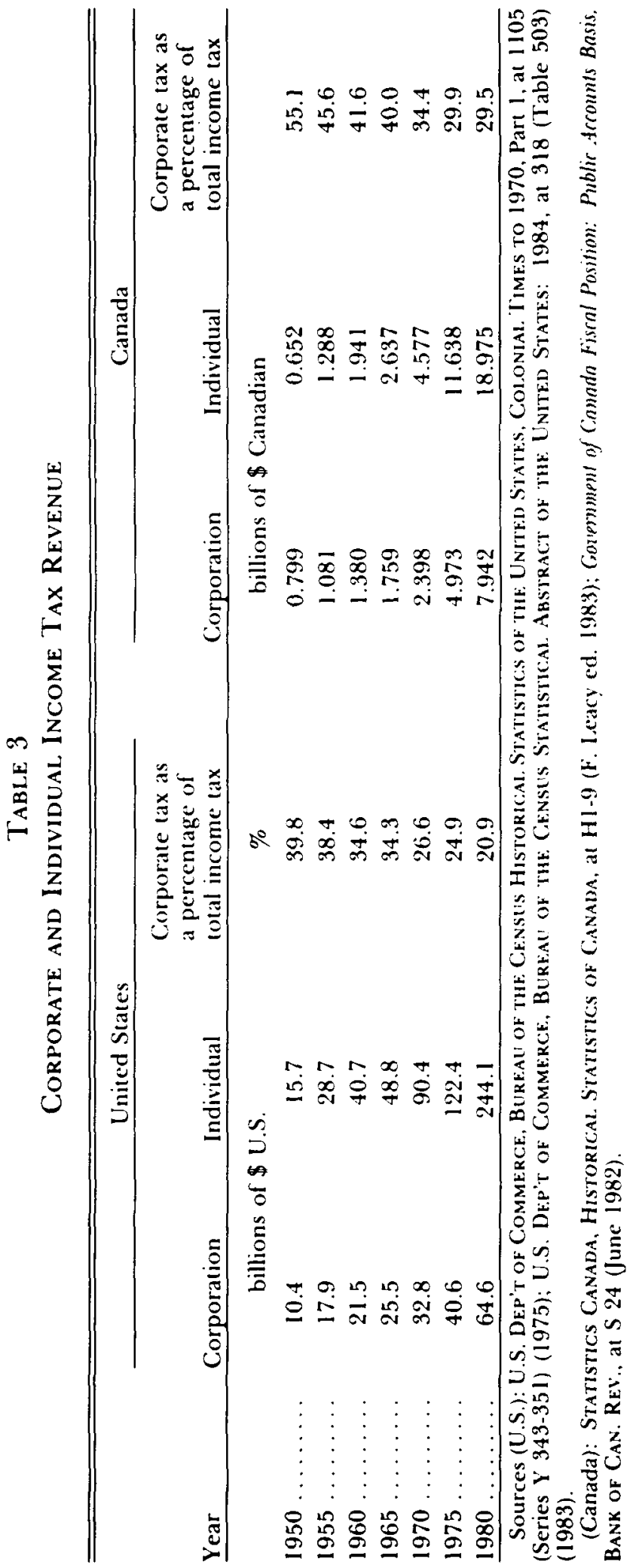


capital income, the attractiveness of a personal consumption tax as a replacement for the income tax will grow. Consumption occurs inherently in dollars of the current year and thus measurement is not distorted by inflation. With a personal consumption tax, there is no need to measure, let alone index, capital income, but under a fair income tax, capital income must be indexed.

There is a certain attractiveness about a personal consumption tax but part of its appeal is based on a false comparison. The ideal personal consumption tax in the literature is compared with the present "tax expenditure" riddled income tax. But believing that an ideal personal consumption tax would be enacted is naive, for lobby groups would demand tax relief for such worthwhile expenditures as housing and schooling. Thus, the case for change in the tax base should not rest on the alleged superiority of an ideal consumption tax but on the superiority of the actual consumption tax which Congress might finally enact only after enormous effort to convince it and the public of the desirability of change. Such an enormous effort would be more effectively expended in obtaining needed reform of the income tax.

The income tax does discriminate against saving as compared to a consumption tax but unless there is a chronic deficiency of saving or an unequivocal efficiency or equity gain, there is no reason to move from an income to a personal consumption tax. Neither consumption nor saving is per se more virtuous than the other. Economic growth may require, at one time, consumption expenditure and, at another, more saving and investment.

The idea that persons should be taxed on the basis of their expenditure and not on their income has some appeal. Nicolas Kaldor has said:

An Expenditure base would tax people according to the amount which they take out of the common pool, and not according to what they put into it . . . . It is only by spending, not by earning or saving, that an individual imposes a burden on the rest of the community in attaining his own ends. ${ }^{226}$

However, the person who saves uses real resources. This use of current resources will permit an increase in future consumption in an amount greater than the current saving. Only the person who puts money under a mattress or in a cookie jar makes no current, direct or indirect, demand on real resources. There does not seem to be any common sense reason for preferring a personal consumption tax. Furthermore, the potential for increased wealth inequality is substantially enhanced under a personal consumption tax as compared with a comprehensive income tax.

For the majority of people who receive little inherited wealth and transmit little wealth, the difference between a personal consumption tax and an income tax is only a matter of timing. Expenditure is high relative to income when people are young and establishing families and also during retirement when accumulated saving is being drawn down. Income is high relative to expenditure in middle age when home mortgages and other debts are being repaid and wealth is being accumulated to finance retirement. Thus, under a

226. N. Kaldor, AN EXPENDITURE TAX 53 (1955). 
personal consumption tax, taxes would be higher during early adulthood and retirement and lower during middle age than under an income tax. However, for the wealthy, there would be a substantial difference between a personal consumption tax and an income tax. Wealth inequality which is already large would probably grow larger.

The two factors causing wealth inequality are inheritance, which transmits wealth inequality from one generation to the next, and income inequality, which currently produces wealth inequality because ability to save increases more than proportionately to income. A person with income at the subsistence level cannot save anything, but persons with high incomes have a large capacity to save and accumulate wealth. Under an income tax, such persons must first satisfy a tax liability with the result that their capacity to save is reduced. Under a personal consumption tax, the amount saved escapes tax. It is not an adequate response to this problem to say that tax rates can be adjusted in order to achieve any desired distribution of the tax burden. Average and marginal tax rates would have to be higher under a personal consumption tax than under a comprehensive income tax because the base is smaller. But the rate structure must be geared to average consumption and therefore could not effectively cope with the wealthy person whose propensity to save is higher than the average. Admittedly, the income tax is a very blunt instrument to use to reduce wealth inequality because it only indirectly attacks the problem. Direct measures such as estate and gift taxes, however, have not been very successful in reducing wealth inequality caused by inheritance. Therefore, there is little reason either to rely on wealth transfer taxes or net wealth taxes in order to reduce wealth inequality directly. It would be a grave mistake to abandon the income tax, for it does moderate unduly large accumulations of wealth.

Deciding whether our basic tax is to be an income tax or a personal consumption tax is imperative. ${ }^{227}$ The current hodgepodge of preference for savings and investment in both the United States and Canada has resulted, at least in part, from a failure to make a clear decision in favor of an income tax. If a personal consumption tax is a possible objective, tax concessions for capital income can be condoned because they simply move one towards that objective. Tax reformers should concentrate on improving the income tax system rather than extolling the attractive features of a personal consumption tax. This was the approach adopted by the Treasury. It studied the relative merits and demerits of a personal consumption tax and concluded that the disadvantages outweighed the advantages. The Treasury noted that "the advantages are purchased at the cost of excluding all capital income from tax,

227. I do not contend that it is essential to have a pure income tax but rather to establish clearly that the basic model is an income tax. Exempting a certain amount of savings to assist persons to accumulate funds for their retirement is acceptable but reasonable limits must be determined. The 1984 proposals by the Department of Finance are commendable in their attempt to rationalize and coordinate the various tax deferral privileges for retirement but I have reservations about the very high absolute limits. Too high a proportion of taxpayers would have the option of transforming an income tax into a consumption tax under those proposals. 
a policy which is questionable on equity grounds." 228 The idea that taxes should be levied on the basis of ability to pay is so firmly ensconced that excluding all saved income from tax will generally be regarded as unacceptable. Tax reform is difficult under any circumstances, but it is probably impossible if it challenges basic ideas about fairness.

Whether the Treasury Report becomes law, it, like the Carter Report, is certain to become a standard to assess other tax reform proposals. The renewed advocacy of a comprehensive income tax base is an important message for the United States and Canada today.

228. 1 Treas. RePORT, supra note 1 , at 211. 
